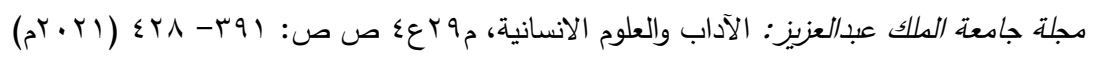

DOI:10.4197/Art.29-4.15

\title{
المتطلبات التربوية لتعزيز الشخصية السعودية لدى طلبة الجامعة في ضوء رؤية المملكة ، r • r من وجهة نظر أعضاء هيئة التدريس
}

\author{
د. أماني محمد بن محمد قليوبي

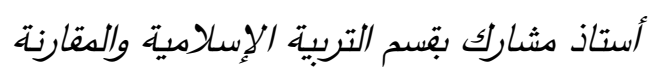 \\ كلية التربية - جامعة أم القرى
}

مستخلص. هدف البحث إلى تحديد أهم المتطلبات التزبوية لتعزيز الثخصية السعودية لدى طلبة الجامعة، في ضوء رؤية الملكة العربية السعودية •r.r.rمن وجهة نظر أعضاء هيئة التدريس، ولتحقيق هذا الهدف تم استخدام المنهج

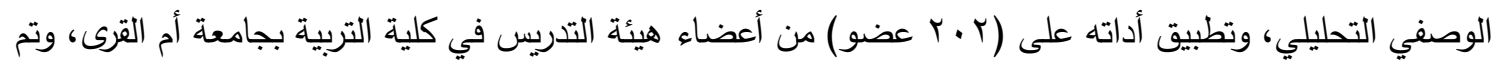

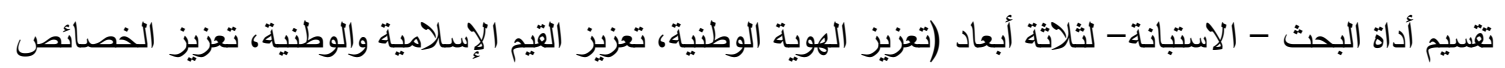

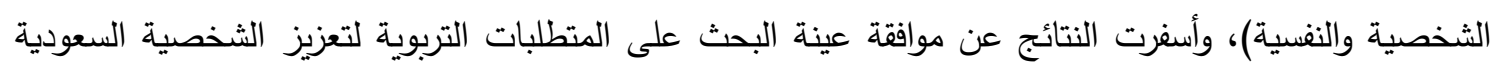

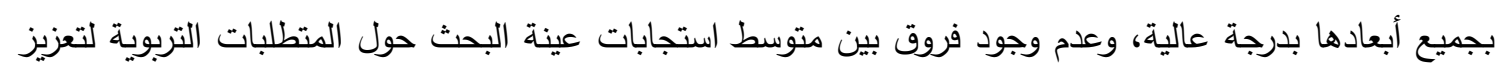

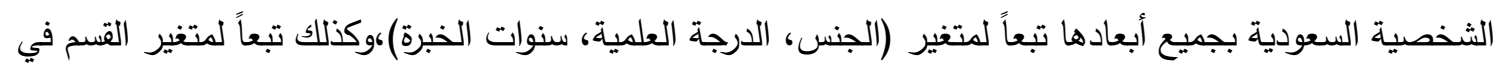

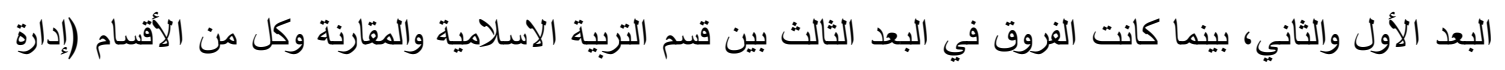

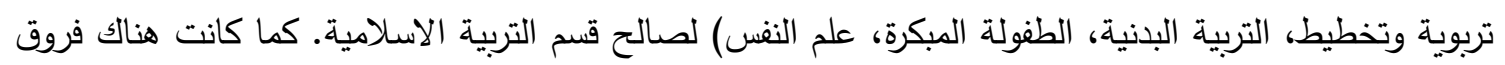

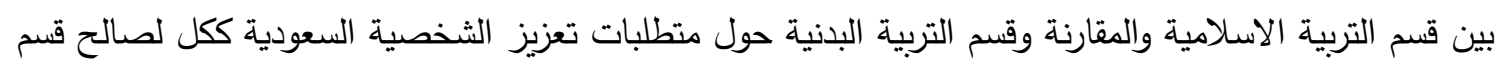

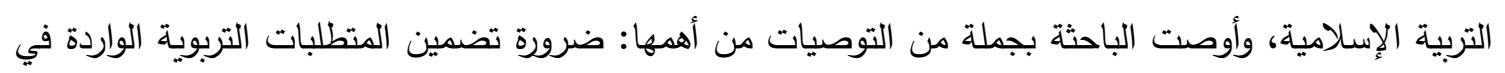

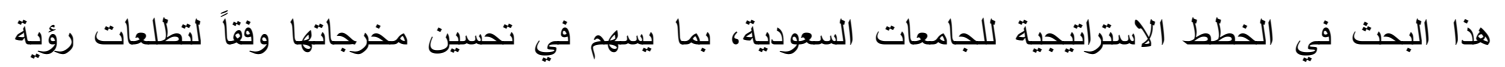
المملكة •r · r اللشخصية السعودية.

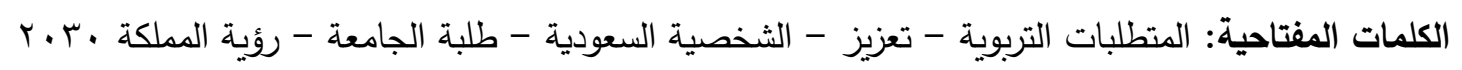

مسبوقة في مجال الاتصالات والإعلام الرقمي،

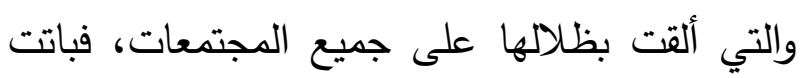
تهدد الخصوصية المجتمعية ، وتؤثر على الثقافات والانتماءات والهوية الوطنية لكل مجتمع.

\section{المقدمة}

يشهد العالم المعاصر انفتاحاً وتتامياً لتيارات العولمة، وما أحدثته من تحديات اجتماعية وثقافية وفكرية

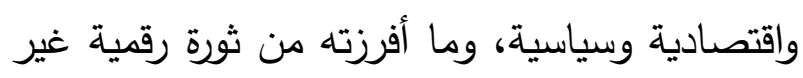


ولكون رؤية المملكة العربية السعودية . ب.r رؤية مستقبلية طموحة - وسعياً لإنجاح استراتيجياتها وتحقيق متطلباتها والأهداف المنشودة منها- فيجب أن تتشارك في تفعيلها كافة المؤسسات المجتمعية الوطنية الرسمية وغير الرسمية، وفي مقدمتها المؤسسات

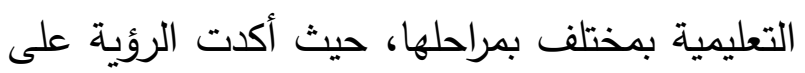

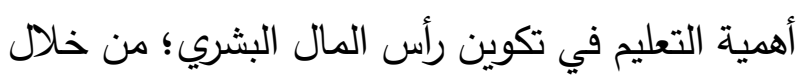
الاهتمام بالبعد الثقافي في بناء شخصية المواطن السعودي، والحفاظ على قيم المجتمع وثوابته، وتطوير قيم المبادرة والمثابرة والقيادة.

ونظراً للمكانة المرموقة للجامعات بين مؤسسات

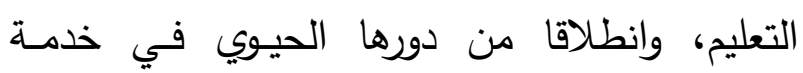
مجتمعها المحلي والوطني يُعَّول عليها القيام بدورٍ

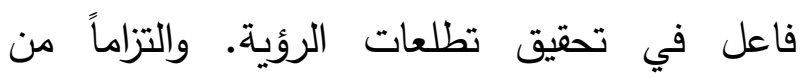
الجامعات السعودية بذلك نجد أنه بعد الإعلان الرسمي لُعي عن رؤية المملكة العربية السعودية •.r.r بتاريخ

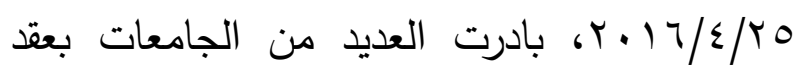
المؤتمرات بما يضمن مساهمتها الفاعلة والمثمرة في

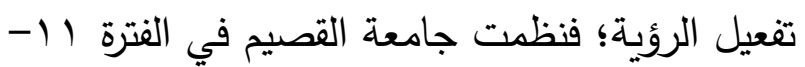

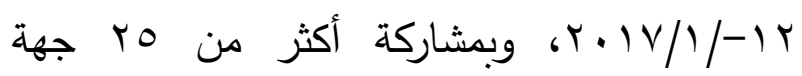
حكومية وأهلية مؤتمراً بعنوان: (دور الجامعات آنات

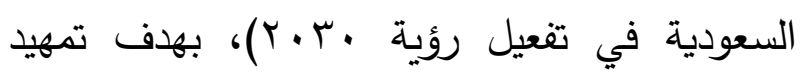
الطريق أمام الجامعات السعودية للمشاركة بفاعلية والاضطلاع بدورها في تحقيق الرؤية.

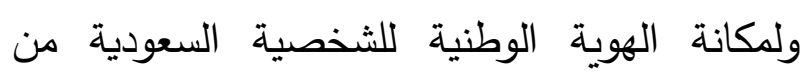
الرؤية، انطلق المؤتمر الدولي للهوية الوطنية في
مما يدعو الدول والمجتمات إلى ضرورة الحفاظ على هويتها وتتمية وتعزيز الشخصية الوطنية لدى أبنائها بكل السبل المتاحة، وهذا ما حرصت عليه المملكة العربية السعودية فكان من أبرز أولويات رؤيتها

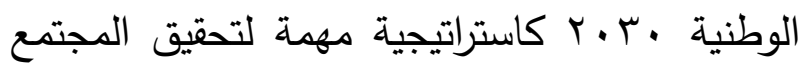
الحيوي الطموح، اهتمامها بالهوية الوطنية، وبتعزيز

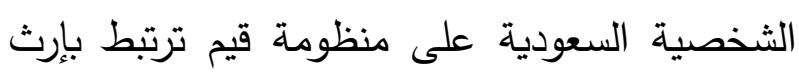
المملكة وعناصر وحدتها ومبادئها الإسلامية الراسخة، صنئه من خلال مبادرات تكاملية تستهدف تعميق الانتماء الوطني، وتعزيز قيم الوسطية والتسامح والإيجابية

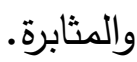

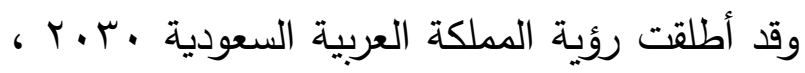
ثلاث عشرة برنامجاً تتفيذياً لتحقيق أهدافها الاستراتيجية، من بين هذه البرامج برنامج "تعزيز الشخصية السعودية"؛ والذي يستهدف تتمية وتعزيز الهوية الوطنية للأفراد وإرسائها على القيم الإسلامية ولية

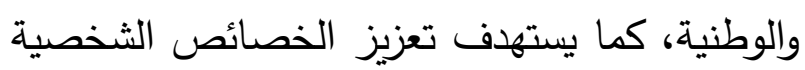

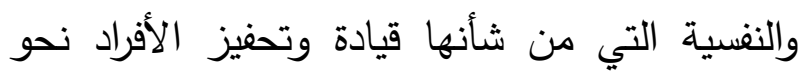
النجاح والتفاؤل، وتكوين جيل متسق وفاعل مع توجه

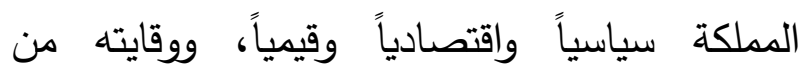
المهددات الدينية والأمنية والاجتماعية والثقافية والإعلامية، مما يرسخ المنجز السعودي الفكري

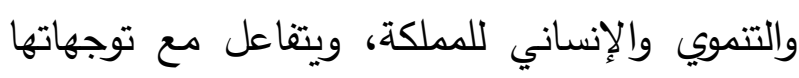

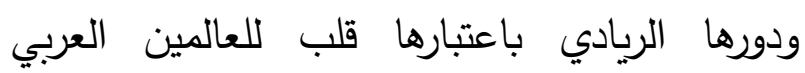
والاسلامي، ويسهر في تصحيح الصورة الذهنية للمملكة خارجياً. (وثيقة رؤية المملكة ، 1 ( • Y). 
ص ص Y Y)، وباعتبار البحث العلمي أحد الوظائف الأساسية للجامعة جاء البحث الحالي ليسهم في تقديم متطلبات تربوية لتعزيز الشخصية السعودية وفق الشقية الرؤية، لدى فئة مهمة في المجتمع ألا وهم طلبة الجامعات قوة الحاضر وقادة المستقبل.

مشكلة البحث

تظل قضية الحفاظ على هوية الشخصية الوطنية وتعزيزها، متصدرة مختلف القضايا في جميع المجتمعات، وخاصة المجتمعات العربية بل أضحت الهاجس الوطني الذي يتصدر المؤتمرات والندوات والخطب الثقافية فيها بجميع أشكالها، فالكثير من الدول في هذه المجتمعات تتعرض لمحاولات النيل منها؛ تحت الادعاء بضرورة إصلاح المجتمع، وأهمية الانفتاح على الغرب، والأخذ بمستحدثات العصر بصرف النظر عن كل ما تبجله تلك المجتمعات من قيم وأخلاقيات. وقد أشار الحارثي (·r.r.r) إلى أن المملكة العربية السعودية، من بين تلك الدول، والتي تتعرض منذ سنوات لمحاولات النيل من هويتها الوطنية وإثارة الشكوك حول فاعلية ثوابتها الدينية والثقافية والاجتماعية(ص Y Y )، الأمر الذي يتحتم معه تعزيز الشخصية السعودية بهويتها المميزة، وإخراجها للعالم كهوية وسطية المنهج والفكر ولتصحيح الصورة الذهنية للمملكة في الخارج. وفي مجتمع معظم مواطنيه من الشباب، توجه اهتمام القيادة لهم كما في كلمة ولي العهد محمد بن سلمان
ضوء رؤية المملكة العربية السعودية • ب • ب، في الفترة

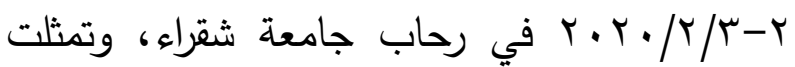
أهداف المؤتمر في ثلاثة أهداف: "تعزيـز الهويـة الوطنيـة وغـرس قيم الانتمـاء والـولاء الوطني وقيـم الوسـطية والتسـامح، ودعم برنامـج تعزيـز الشـخصية السـودية كأحد أهـم البرامـج الاسـتراتيجية لرؤيسة

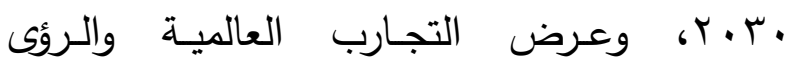
الاستشـرافية في مجـال تعزيـز الهويـة الوطنيـة "

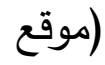
(https://apps.su.edu.sa/NationalConfe، المؤتمر .rence/pages/e2.html كما حددت جامعة الملك سعود عنوان المؤتمر الذي نظمته جمعية جستن التابعة للجامعة بـ (تعزيز الشخصية السعودية لمجتمع حيوي) والمنعقد في الفترة

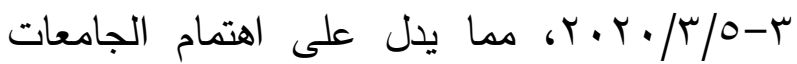
السعودية بتعزيز الشخصية الوطنية انطلاقاً من اهتمام الرؤية بتعزيز الشخصية السعودية المنبثقة من اهتمام القيادة الرشيدة بهذا الجانب. تأسيساً على ما سبق فإن الجامعات السعودية وبما يتوفر لها من إمكانات مادية وبشرية عليها أن تسهم بشكل كبير في تعزيز الشخصية الوطنية لدى طلابها وخريجيها، ونشرها للعالم كهويـة تعزز قيم الوسطية والتسامح والإيجابية والمثابرة المنبثقة من مبادئها الإسـلامية الراسخة وإرثها الثقافي المتنوع، وأن تتكامل جهودها مع برامج الرؤية المختلفة لترسيخ المنجزات

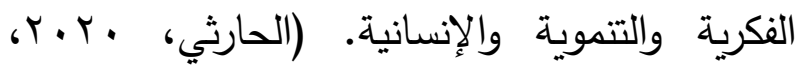


بعض أبنائها أمام الزحف الفكري والإعلامي والذي كان سبياً في تخلخل مكونات شخصيتهم وابتعادهم عن مبادئ الدين الإسلامي السمحة والمعتدلة

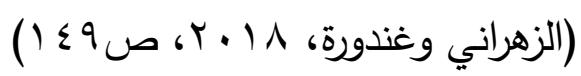

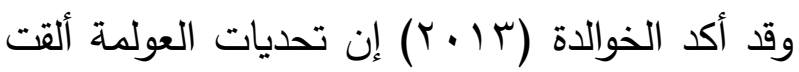
بظلالها على الثباب الجامعي، وانعكست على منظومة القيم لديهم، فقد ظهرت لديهم ممارسات

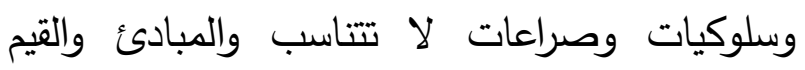
الدينية والوطنية، ومن هذه الممارسات التقليد الأعمى ولى ولئ

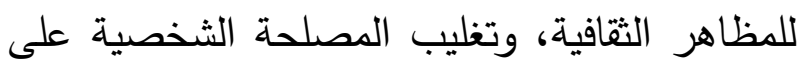
المصلحة العامة، بالإضافة للعنف والتعصب، وغيب ولياب

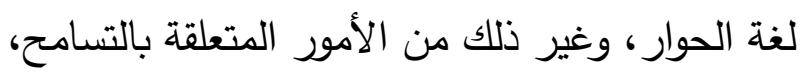
والانتماء، واحترام الرأي الآخر (صن • 11 (1). وبذلك يمتد دور الجامعات إلى بناء شخصية الطالب السعودي الناهضة الواعية المؤهلة المتسلحة بالدين

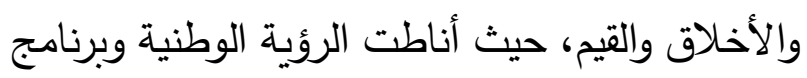
التحول الوطني دوراً متعاظماً للتعليم في ترسيخ القيم

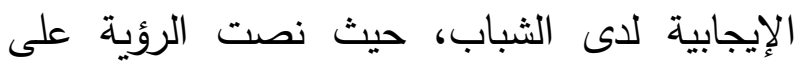
الهدف التالي" ترسيخ القيم الإيجابية في شخصيات أبنائنا عن طريق تطوير المنظومة التعليمية والتربوية، وتوفير تعليم قادر على بناء الثخصية"(وثيقة رؤية المملكة ، 7 ( • ب). وفي سياق الاهتمام بأدوار الجامعة بعامة، ييرز الدور

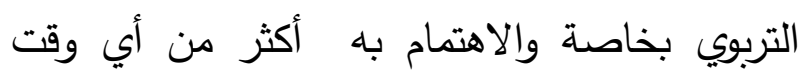
مضى؛ في ظل ما يموج به العالم من تحديات

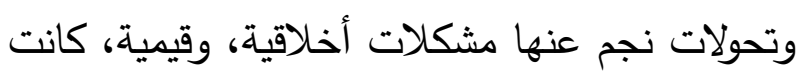

في افتتاحية رؤية المملكة • · • ب " في بلادنا ثروات

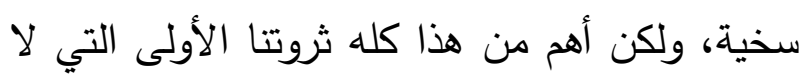

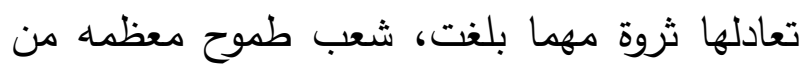
الشباب، هو فخر بلادنا وضمان مستقبلنا بعون الله

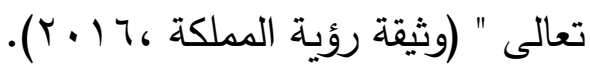
مما يُجسد الدور المهم للجامعات السعودية في التنمية الوطنية، وذلك من خلال بناء واستيعاب الثباب -أهم ثروات البلاد- وتعزيز شخصيتهم الوطنية وتسليحهم بروافد العلم والمهارة والمعرفة. ونظراً للمكانة المرموقة للجامعة في المجتمع من بين مراحل التعليم، فإنه تقع على عاتقها مسؤوليات، ووظائف جمة في سبيل تعزيز الثخصية الوطنية لدى أفراد المجتمع، مما يستلزم قيامها باستثمار رؤية

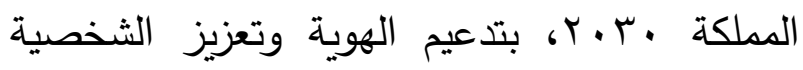
الوطنية لمنسوبيها وبدرجة أكبر لطلبتها؛ نظراً لأنهم الفئة العمرية الأكثر عرضة للتشويه والتغريب؛ فهم الأكثر تأثراً بالمتغيرات والتحديات الثقافية والفكرية الوافذة، فمعظم الجامعات تعاني من ظواهر اجتماعية وتربوية سلبية نتيجة العديد من المتغيرات المعاصرة،

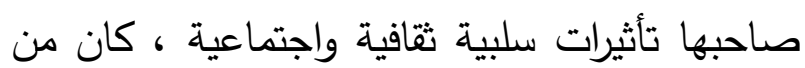
نتائجها ظهور اتجاهات وقيم غريبة على ثقافتنا تتعكس سلباً على شبابنا الجامعي وعلى هويتهم

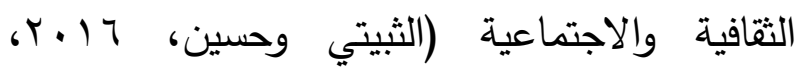

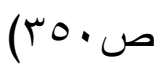
كما أن من أبرز التحديات التي تواجهها الأمة اليوم ما تشهده من ضعف وتطرف وغلو في شخصيات 
وتتم الإجابة عن السؤال الرئيس السابق من خلال الإجابة على الأسئلة الفرعية التالية:

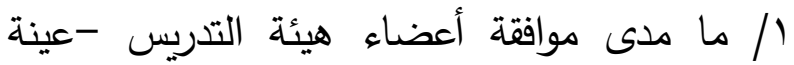
البحث- حول المتطلبات التربوية لتعزيز الثخصية السعودية للى طلبة الجامعة من خلال تعزيز (الهوية

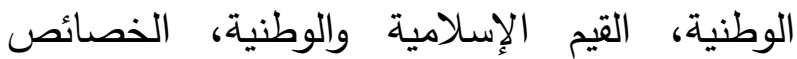
الشخصية والنفسية) وذلك من وجهة نظرهم في ضوه

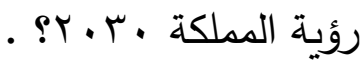
/ / هل توجد فروق ذات دلالة إحصائية بين متوسط استجابات أعضاء هيئة التدريس -عينة البحث-حول المتطلبات التربوية لتعزيز الثخصية السعودية لدى لهى

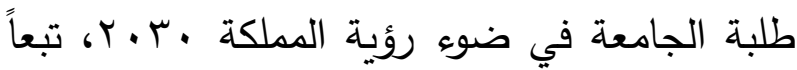

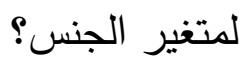

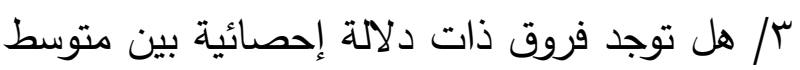
استجابات أعضاء هيئة التدريس -عينة البحث-حول المتطلبات التربوية لتعزيز الشخصية السعودية لدى

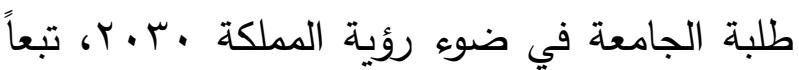

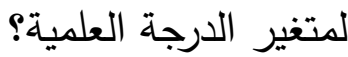
ء / هل توجد فروق ذات دلالة إحصائية بين متوسط استجابات أعضاء هيئة التدريس -عينة البحث-حول المتطلبات التربوية لتعزيز الثخصية السعودية لدى

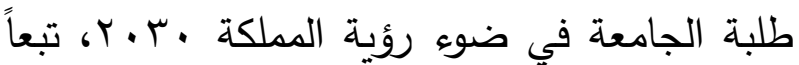

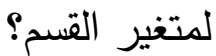
/ هل توجد فروق ذات دلالة إحصائية بين متوسط استجابات أعضاء هيئة التدريس -عينة البحث-حول

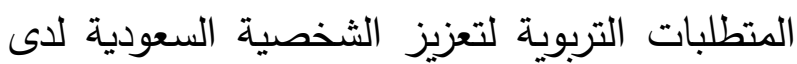

الفئة الأكثر تعرضا لها هم فئة الثباب الجامعي، حيث أثرت على شخصياتهم وبنائهم القيمي واعتزازهم

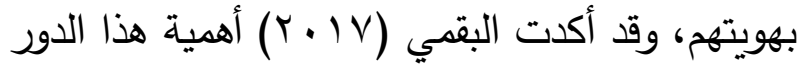
بأن الجامعات مطالبة بالإسهام التربوي في تحقيق رؤية •r.r.r، فعليها المعول في مواكبة تطورات العصر ومتغيراته، فهناك جملة من المتطلبات التربوية التي ينبغي أن تؤخذ في الاعتبار ليتمكن الطلبة من فن

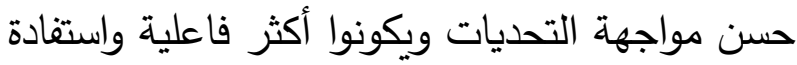
من منجزات هذا العصر (ص •r" ا). وهذا يتطلب من الجامعات إعطاء الجانب التربوي اهتماماً أكبر مما هو عليه حالياً فتحقيقه في شخصية الطلبة يتطلب تكاملاً تعليمياً وتربوياً، وتوفير بيئة أكاديمية تربوية لهم تتماشى مع توجهات الرؤية، للخروج بالمنجزات السعودية التي تحاكي تطلعات الوطن لشخصية المواطن السعودي في القرن الواحد والعشرين. ولأهمية برنامج تعزيز الشخصية السعودية في رؤية

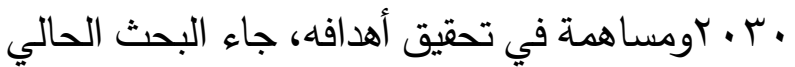
ليعاضد الدراسات التي تتاولت تعزيز الشخصية السعودية لدى طلبة الجامعات في ضوء الرؤية، كما يعد مساهمة في تفعيل أحد البرامج الاستراتيجية في الرؤية، هذا وتتحدد مشكلة البحث في السؤال الرئيس

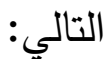
ما المتطلبات التربوية لتعزيز الثخصية السعودية لاى طلبة الجامعة من وجهة نظر أعضاء هيئة

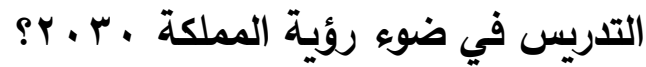




$$
\text { أماني محمد بن محمد قليوبي }
$$

Y-عناية رؤية المملكة العربية السعودية •r.r بتخصيص برنامج وطني استراتيجي يختص بتعزيز

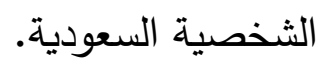
ب-لأهمية معرفة المتطلبات التربوية اللازمة لتعزيز الثخصية السعودية، والإفادة منها عملياً لتعزيز الجوانب الإيجابية في شخصية الطالب الجامعي بما تحمله من قيم واتجاهات وعادات. ع-تأمل الباحثة أن تسهم نتائج البحث في تطواته تهادير دور الجامعات السعودية من حيث صياغة أهدافها، وتحديد أدوارها الجديدة، وتوفير الإمكانات اللازمة بما يحقق منقاع تعزيز تلك المتطلبات التزبوية لدى الطلبة في ضوه

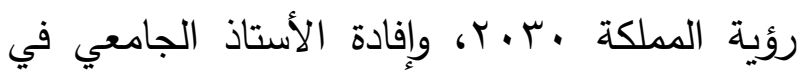
تطوير دوره التربوي من خلال تتمية شخصية الطلبة وفقاً للمتطلبات التربوية التي يقدمها البحث. حدود البحث 1-الحدود الموضوعية: يقتر البحث على المتطلبات التربوية لتعزيز الثخصية السعودية في ثلاثة أبعاد هي: (تعزيز الهوية الوطنية، تعزيز القيم الإسلامية والوطنية، تعزيز الخصائص الشخصية والنفسية). r-الحدود البشرية والمكانية: أعضاء هيئة التدريس بكلية التربية بجامعة أم القرى بمرتبة (أستاذ، أستاذ مشارك، أستاذ مساعد). r-الحدود الزمانية: تم تطبيق أداة البحث في الفصل الثاني من العام الدراسي ب ؟ ـ أهـ.
طلبة الجامعة في ضوء رؤية المملكة .ب.r. تبعاً

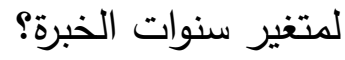
أهداف البحث

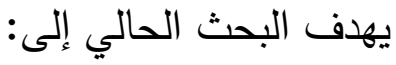
1-تحديد أهم المتطلبات التربوية لتعزيز الثخصية السعودية لاى طلبة الجامعة، في ضوء برنامج تعزيز

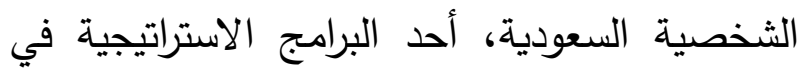
رؤية المملكة العربية السعودية •.r.r. r- التعرف إلى مدى موافقة أعضاء هيئة التدريس عينة البحث- حول المتطلبات التربوية لتعزيز الثخصية السعودية لدى طلبة الجامعة من خلال تعزيز (الهوية الوطنية، القيم الإسلامية والوطنية، الخصائص الشخصية والنفسية) وذلك من وجهة نظرهم في ضوء رؤية المملكة . . . r؟؟ . r-الكثف عن الفروق بين متوسطات استجابات أفراد عينة البحث حول المتطلبات التربوية اللازمة لتعزيز الثخصية السعودية لدى طلبة الجامعة تبعاً للمتغيرات (الجنس، التخصص، الدرجة العلمية، سنوات الخبرة). أهمية البحث يكتسب البحث الحالي أهميته من حيث الآتي: 1-أهية موضوعه في الوقت الحالي وما يعيشه العالم من انفتاح واندماج ثقافي واجتماعي واقتصادي، وما قد يحدثه من تأثيرات على مستوى الهوية الوطنية، بما تحمله من سمات وخصائص متعددة ومؤثرة في تشكيل

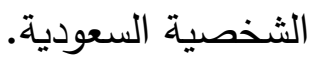


التي تميز المواطن السعودي عن غيره، والتي يعتز بها وتشكل جوهر وجوده وشخصيته، وتصوره عن

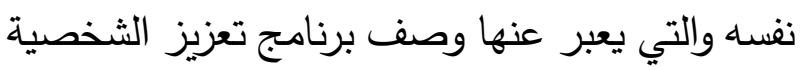
السعودية -أحد برامج رؤية المملكة • • . ب- وأهدافه.

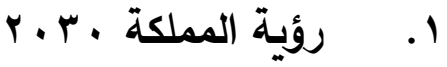

هي خطة ما بعد النفط للمملكة العربية السعودية تم

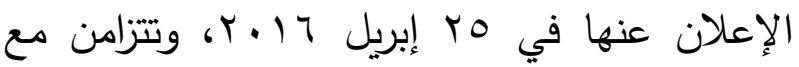
التاريخ المحدد لإعلان الانتهاء من تسليم •^ مشروعاً

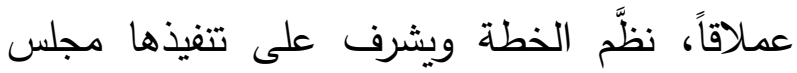
الثؤون الاقتصادية والتتمية، ويشترك في تحقيقها كلاً من القطاع العام والخاص وغير الربحي. تتلخص

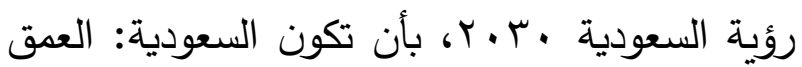
العربي والإسلامي، والقوة الاستثمارية الرائدة، ومحور ربط القارات الثلاث، وتعتمد على ثلاثة محاور: مجتمع حيوي، اقتصاد مزدهر، وطن طموح. (وثيقة

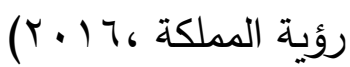
وتعرف الباحثة المتطلبات التربوية لتعزيز الشخصية

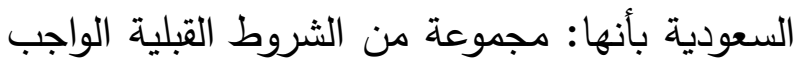
توافرها لاى الطلبة الجامعيين لاعم شخصيتهم السعودية فيما يتعلق بالجانب التربوي، لتحقيق رؤية

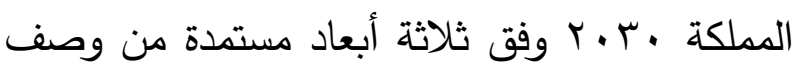
برنامج تعزيز الثخصية السعودية وأهدافه تتمثل في (تعزيز الهوية الوطنية، تعزيز القيم الإسلامية والوطنية، تعزيز الخصائص الثخصية والنفسية).
مصطلحات البحث

-المتطلبات التربوية

المُنطلبات: جمع متطلب، ومادة (طلب) في اللغة: تدل على محاولَة وجدان الثيء وأَخذه، وتطلبه: حاول وجوده وأخذه، والتطلب: الطلب مرة بعد أخرى (ابن

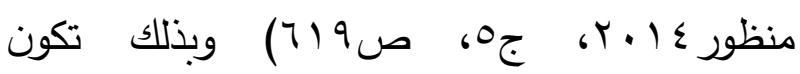
المتطلبات شروط قبلية لازمة لوجود الثيء. والمتطلبات التربوية: عرفها القطب (997 (199) بأنها "تغيرات يلزم إجراؤها في كل من الفكر والتطبيق التربويين استجابة لتغيرات في الفكر والتطبيق خارج النسق التربوي" (صَ7). وتقصد الباحثة بالمُتطلبات التربوية: مجموعة من الأمور والثروط التربوية التي لا بد من توفرها؛ لتدعيم وتقوية الثخصية السعودية في طلبة الجامعة. - تعزيز الشخصية السعودية -التعزيز : "تدعيم السلوك المناسب أو زيادة احتمالات تكراره في المستقبل بإضافة مثيرات إيجابية أو إزالة

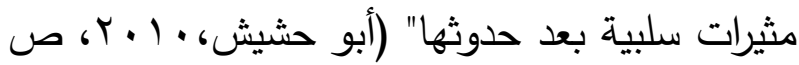

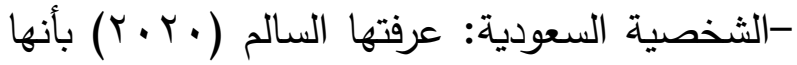
"البصمة الذاتية للفرد أو الجماعة التي يكونها خلال مراحل حياته وتكونت بوعيه الثقافي والاجتماعي وأصبحت بمثابة جوهره الأصيل لكيانه الذي يميزه عن ونائ غيره من الفراد والجماعات الأخرى" (صهمه). وتقصد الباحثة بتعزيز الشخصية السعودية: تدعيم مجموعة السمات والاتجاهات والخصائص المشتركة 
الشخصية السعودية لدى الطلبة، وكذلك إسهام أعضاء هيئة التدريس والإدارة الجامعية. - دراسة (السبيعي، 9 1 م ب): هدفت إلى تقديم تصور مقترح لتعزيز الشخصية السعودية في ضوء رؤية المملكة، ولتحقيق هذا الهدف اعتمدت الدراسة على المنهج الوصفي، وتمثلت نتيجة الدراسة في تقديم التصور المقترح.

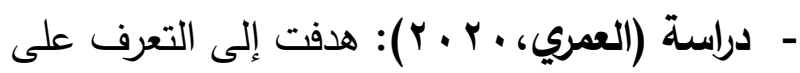
دور جامعة الجوف في تعزيز الثخصية الوطنية لدى طلبتها، من وجهة نظر أعضاء هيئة التدريس، والكثف عن أبرز التحديات التي تواجه الجامعة للقيام بدورها، وقد اعتمدت المنهج الوصفي المسحي، وأظهرت النتائج أن دور جامعة الجوف جاء بمستوى متوسط، كما تمثلت أبرز التحديات التي تواجه الجامعة دونة في ضعف دعم القطاع الخاص للبرامج والأنشطة الهادفة لتعزيز الثخصية الوطنية، وتأثير العولمة وما نتج عنها من انتثار ثقافات دخيلة. - دراسة (آل هشبول، • • • Y): هدفت إلى التعرف على واقع دور الجامعات الحكومية في تعزيز الشخصية السعودية تحقيقا لرؤية •.r.r من وجهة نظر القيادات الأكاديمية، واستخدم الباحث المنهج

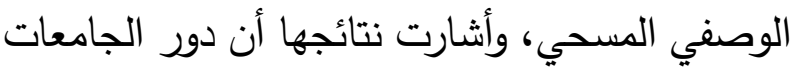
جاء بدرجة متوسطة.

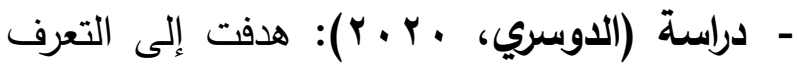
على دور الجامعة في تعزيز الشخصية السعودية من أجل تتمية قيم المواطنة لدى الطلبة وتعزيز الانتماء
الدراسات السابقة تناولت العديد من الدراسات دور التعليم الجامعي في تعزيز الهوية الوطنية أو أحد أبعادها، كما تتاولت دراسات أخرى دور التعليم الجامعي في تحقيق رؤية المملكة .r.r.r، إلا أن الباحثة ستقتصر على عرض لدري الدراسات التي تتناول دور الجامعات في تعزيز الثخصية السعودية وفق رؤية المملكة لصلتها المباشرة بالبحث الحالي، كما ستعرض الدراسات التي قدمت متطلبات تربوية لطلبة الجامعة وفق رؤية المملكة، وسيتم عرضها من الأقدم للأحدث:

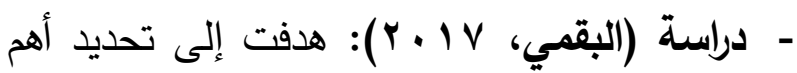
المتطلبات التربوية اللازمة لطالبات المرحلة الجامعية من وجهة نظر الطالبات، في ثلاثة مجالات: التعليمية، الاجتماعية، والاقتصادية في ضوء رؤية

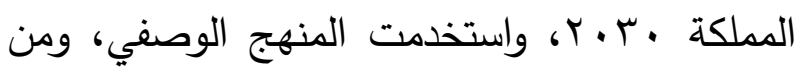
نتائج الدراسة تقديم اء متطلباً تربوياً في المجالات التهي الثلاث، وموافقة أفراد عينة البحث على عبارات جميع المحاور بدرجة عالية.

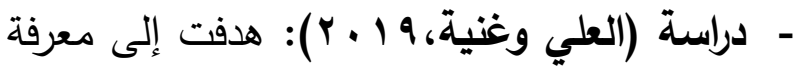
واقع مناهج الدراسات العليا في تعزيز الشخصية السعودية لدى طلاب كلية التربية بجامعة الأمير سطام

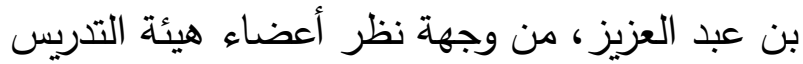
وفق رؤية •r.r. استخدم الباحثان المنهج الوصفي المسحي، وأظهرت نتائج الدراسة أن أهداف مناهج الدراسات العليا ومقرراتها تسهم بدرجة قوية في تعزيز 


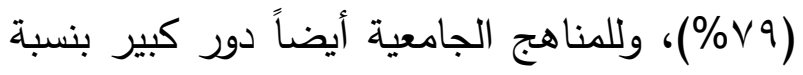

تعقيب عام على الاراسات السابقة من خلال ما تم عرضه من دراسات سابقة اتضح الاهتمام الكبير الموجه من قبل الجامعات لتحقيق رؤية

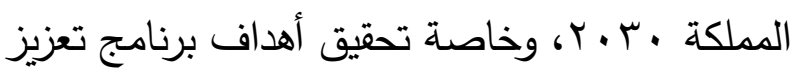
الشخصية السعودية لدى الطلبة، كما نلحظ التالي: - تناولت الدراسات السابقة أدوار الجامعة في تعزيز

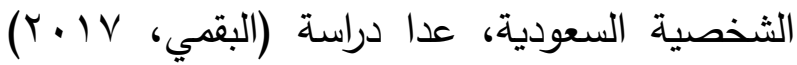
التي قدمت متطلبات تربوية لتحقيقها في الطالبات في ضوء الرؤية بعامة دون تحديدها في تعزيز الثخصية السعودية، ودراسة (السبيعي، 9 ـ ب) التي لم تتناول أدوار الجامعة بل قدمت تصوراً مقترحاً لتعزيز

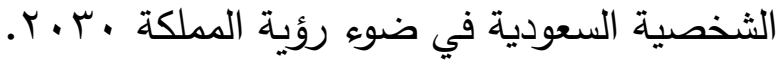
- كما اقتصرت بعض الدراسات على دور الجامعة في تعزيز الشخصية السعودية على جانب واحد كدراسة (العلي وغنية، 9 • ب) والتي تناولت واقع مناهج الدراسات العليا في تعزيز الشخصية السعودية،

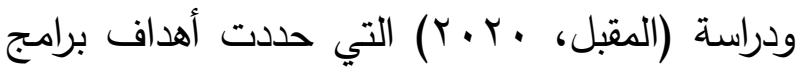

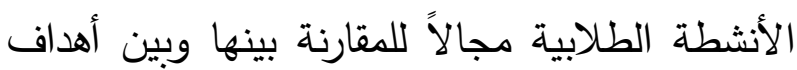
برنامج تعزيز الشخصية السعودية ومدى تحقيقها له،

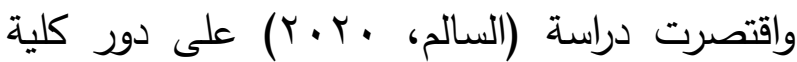
التربية في الجامعة، كما اقتصرت دراسة (الدوسري،

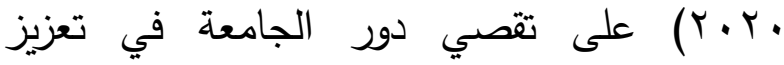
الشخصية من جانب واحد وهو تنمية قيم المواطنة.
الوطني، واستخدمت الباحثة المنهج الوصفي، ومن أبرز نتائج الدراسة وجود إدراك عام لدى الطلبة بأهمية الانتماء والولاء للوطن وهو ما يمثل أعلى قيم المواطنة، ووجود ارتباط دال إحصائياً بين دور الجامعة في تعزيز قيم المواطنة وبين إدراك الطلبة لتلك القيم.

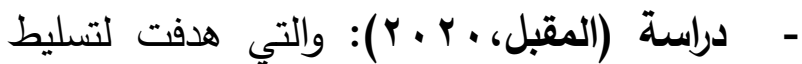
الضوء على برنامج تعزيز الثخصية السعودية

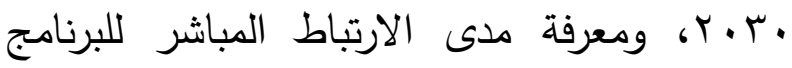

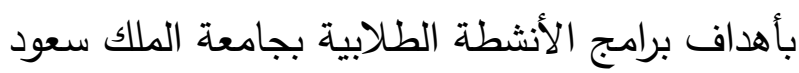
بن عبد العزيز للعلوم الصحية؛ وللتحقق من مدى

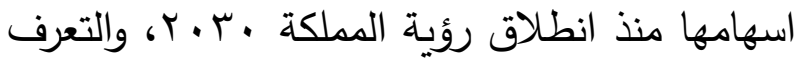
على البرامج الطلابية المهتمة بالعناية في المتميزين كأحد الأهداف المباشرة للشخصية السعودية بالرؤية، واستخدمت الدراسة المنهجي الوصفي، ومن أبرز نتائجها أن أهداف برامج الأنشطة الطلابية تلتقي بالأهداف المباشرة لبرنامج تعزيز الثخصية السعودية .r.r.

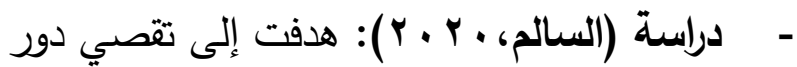

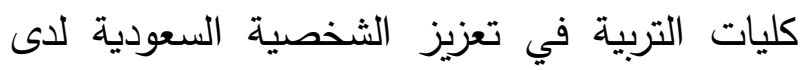

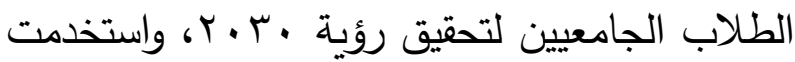
المنهج الوصفي التحليلي، ومن أهم النتائج التي

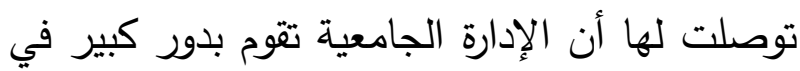
تعزيز الشخصية السعودية لدى الطلاب الجامعيين

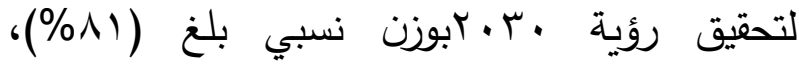
ولأعضاء هيئة التدريس كذلك دور كبير بوزن نسبي 


$$
\text { أماني محمد بن محمد قليوبي }
$$

الفرد الفيزيقية والعقلية والخلقية والاجتماعية، كما يعبر عن نفسه أمام الأخرين في مظاهر الأخذ والعطاء في الحياة الاجتماعية. وهي بهذا تشمل الجوانب الطبيعية

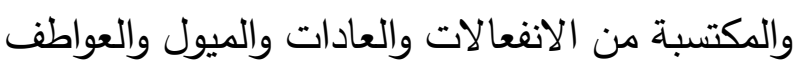

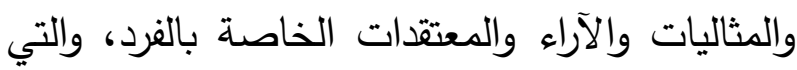

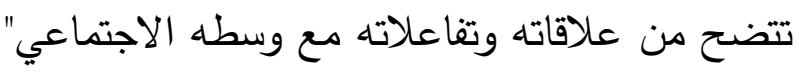

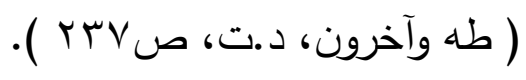

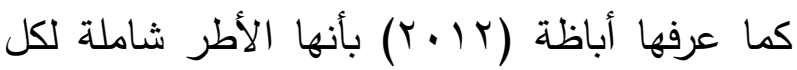
خصائص الثخص في صورة دينامية وتشمل على كل صفة تميز الفرد وتجعله فريداً مميزاً عن الآخرين مع دع دين الاعتراف بوجود قدر من التشابه(ص rی) .

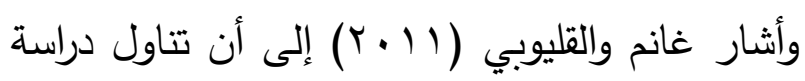
الشخصية لا يكون من منطلق واحد، بل يختلف باختلاف اتجاه البحث، فعلى سبيل المثال إن تتاول شخصية الفرد يكون مختلفاً عن آليات تتاول شخصية لئيل الجماعة أو المجتم. لذا فإن مفهوم الشخصية السعودية يكون وفقاً لمفهوم الشخصية الوطنية وليس لهن لهني مفهوم الشخصية على الإطلاق (صدم (1). مفهوم الشخصية الوطنية: هي مجموعة السمات الإطلية

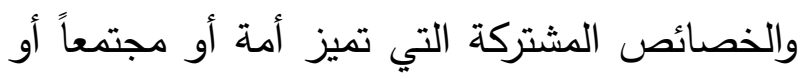
وطناً معيناً من غيره، يعتز بها وتشكل جوهر وجوده

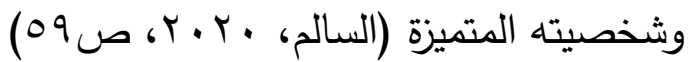
الشخصية السعودية: هي "ارتباط المواطن السعودي بقيم وتعاليم الدين الإسلامي وانتمائه لقيم وثقافة وعادات مجتمعه والتزامه بالأنظمة والقوانين واحترام
- يتناغم البحث الحالي مع الدراسات السابقة في اهتمامه بالمرحلة الجامعية ومساهمتها في تحقيق رؤية لبية الممكة •.r.r، وبخاصة تعزيز الشخصية السعودية لاى طلبة الجامعات، ويتثق مع دراسة (البقهي،

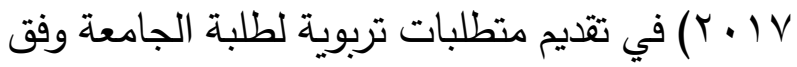

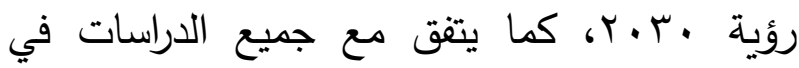
استخدامه المنهج الوصفي. - يختلف البحث الحالي عن بقية الدراسات من حيث هدفه المتمثل في تقديم المتطلبات التربوية لتعزيز الشخصية السعودية لدى طلبة الجامعة وفق رؤية المملكة . . . . و وهو مالم تتناوله أياً من تلك الدراسات. الإطار النظري

\section{أولاً/ الثخصية السعودية النطية

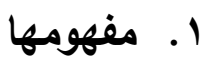

يعتبر موضوع الثخصية مجال اهتمام الكثير من العلوم الإنسانية المختلفة (علم النفس بمجالاته المختلفة - علم الاجتماع- الطب النفسي) كما أنها مثار اهتمام غير المتخصصين مثل الفنانين والثعراء ومؤلفي الروايات وعامة الجمهور المثقف وكل إنسان. ولتوضيح مفهوم الشخصية السعودية يجب توضيح مفهوم الشخصية ومدلولها. ولعل المفهوم الأقرب للبحث الحالي هو مفهومها في علم النفس، ومن ثم التعريج على مفهوم الثخصية الوطنية بعامة، وصولا لـفهوم الثخصية الوطنية السعودية. الشخصية: جاء تعريفها في معجم علم النفس والتحليل النفسي بأنها "التنظيم الدينامي المتكامل لخصائص فئ 


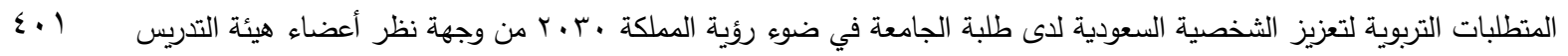

كما يعتبر الدين الإسلامي في المملكة مبعث القيم

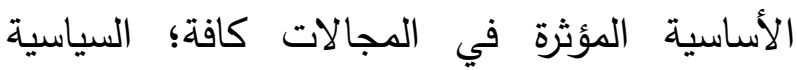
والقضائية والتشريعية والتعليمية والاجتماعية والاقتصادية والتعليمية، بالإضافة لتأثيره في السياسات العامة والعلاقات الخارجية، وهذا ما لإلان تضمنته المادة الأولى من النظام الأساسي للحكم "أن المملكة العربية السعودية دولة إسلامية ذات سيادة تامة، دينها الإسلام ودستورها كتاب الله تعالى وسنة رسوله صلى الله عليه وسلم" (هيئة الخبراء بمجلس الوزراء، https://old.boi.gov.sa). ب- المكون اللفوي: تعد اللغة عنوان الثخصية الإنسانية، ووسيلة التفاهم والتعلم والحضارات، واللغة

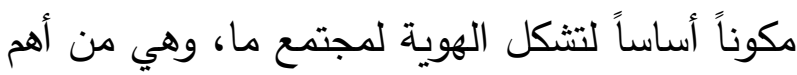
مقومات الهوية التي تميز الدول وتحفظ كيانها واستقلاليتها لذا حرصت جميع الدول على التمسك لتكيرك بلغتها.

واللغة العربية تتميز عن غيرها من اللغات بما حملته

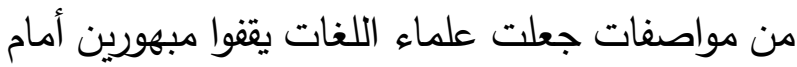
عظمتها وفصيح معانيها وتماسك ألفاظها

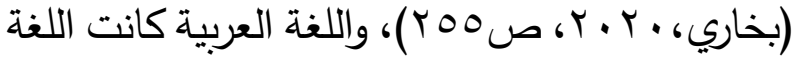
المحلية لسكان الجزيرة العربية قبل الإسلام، وزادها الإسلام شرفا ورفعة حين جعلها لغة القرآن الخالدة، فالتمسك بها والحرص على رفعتها وعلو شأنها واجب

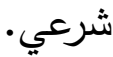
وتعتبر اللغة العربية إحدى أهم مكونات هوية الشخصية السعودية؛ لأنها عنصر وحدة المجتمع
حريات الآخرين التي من شأنها تمثيل المملكة العربية

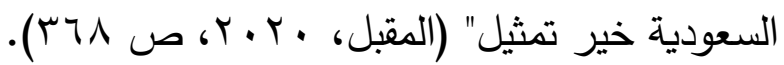

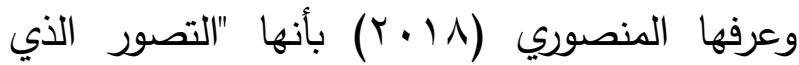
يكونه الشعب السعودي عن ذاته، في كل مرحلة من مراحل تطوره وهي نتاج عن تميزه عن الآخرين وهي تمثل هويتهم الوطنية" (ص بr). وعرفت السالم (·.r.r) الثخصية السعودية بأنها البصمة الذاتية للفرد أو الجماعة التي يكونها خلال مراحل حياته وتكونت بوعيه الثقافي والاجتماعي وأصبحت بمثابة جوهره الأصيل لكيانه الذي يميزه عن غيره من الأفراد والجماعات الأخرى (صیهه). r - r - مكوناتها تتكون هوية الثخصية السعودية من جملة من المكونات، تآزرت فيما بينها وتكاملت، أثر كل مكون فيها بالآخر وتأثر به، ويمكن إجمال تلك المكونات

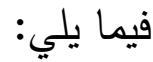
أ- المكون الديني: يمثل الدين الإسلامي وفق المنهجية السلفية الصحيحة المكون الأول والأساس الصنسي لهوية الشخصية السعودية، فالمملكة العربية السعودية دولة إسلامية وجميع مواطنيها يعتتقون الإسلام الذي يسبغها بهويتها الخاصة والمتفردة التي لا تضاهيها هوية أخرى. كما أن المملكة تقود العالم الإسلامي إذ الذ

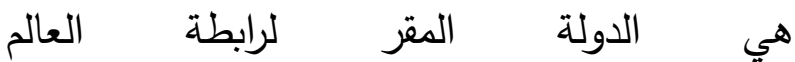

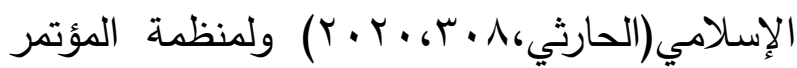

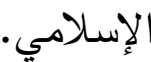




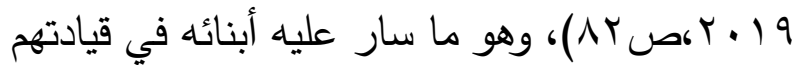
الرشيدة إلى الآن، تجسده مواقف المملكة قيادة وشعباً تجاه القضايا العربية وعلى رأسها قضية فلسطين، كما لأجداء أن المملكة كانت إحدى الدول المؤسسة لجامعة الدول

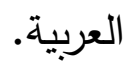
د-المكون الجعرافي: ليتمثل كيان أي مجتمع فلابد له

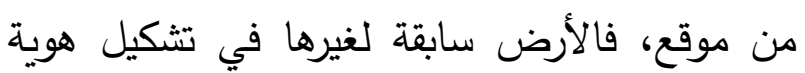
الثخصية الوطنية؛ فعليها يعيش أصحاب الهوية. وقد توحدت أجزاء الحكم السعودي وفق الحدود السياسية تحت مسمى "المملكة العربية السعودية"

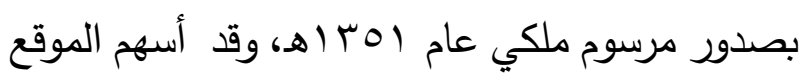
الجغرافي المتميز للمملكة في تشكيل هوية الشخصية

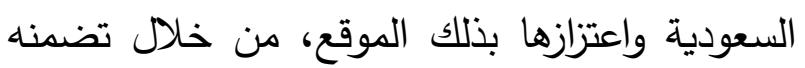
مكة المكرمة مهبط الوحي وقبلة المسلمين، والمدينة المنورة مثوى النبي صلى الله عليه وسلم، وتضم أرجائه الحرمين الثريفين والمشاعر المقدسة، التي تعد التي مشتركاً مقدساً من جميع المسلمين، مما جعل أبناء

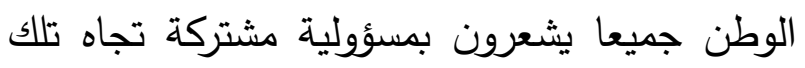

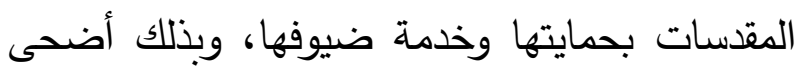

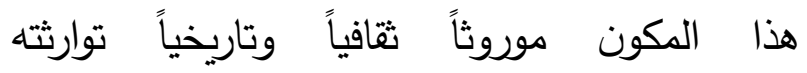

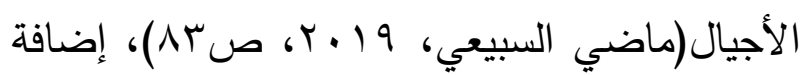

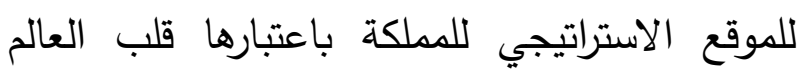
ورابطة القارات الثلاث، وما تمتلكه من ثروات سخية لهنية من أهمها البترول وفيها ثروات سخية من الذهب والفوسفات واليورانيوم وغيرها مما جعل لها أهمية كبرى هن الهن

اقتصادياً.
السعودي، وهي الوعاء الحاضن لثقافته وحضارته؛ فهي لغة التخاطب والمكاتبات الرسمية والحكم والإدارة وهذا ما أكده النظام الأساسي للحكم في مادته الأولى ولى

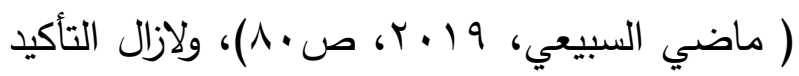
على استخدام اللغة العربية كلغة أساسية رسمية، يؤكد

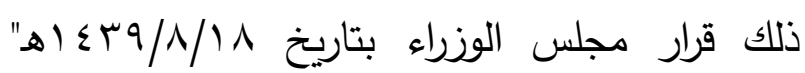
باعتماد اللغة العربية لغة رسمية في المؤتمرات والندوات التي تنظم داخل المملكة العربية السعودية، مع جواز استخدام لغة أخرى في المؤتمرات والندوات التخصصية التي تستلزم ذلك، مع الترجمة الفورية "(وكالة السعودية، .(https://www.spa.gov.sa كما أكدت (وثيقة سياسة التعليم في المملكة، 990 (1) ) فبأن" الأصل هو أن اللغة العربية لغة التعليم في كافة لئل

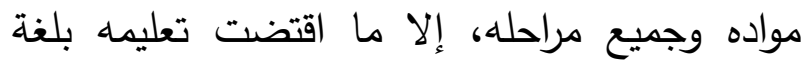

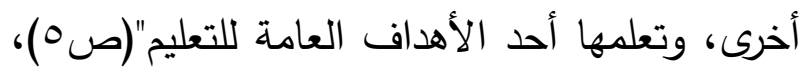
كما أن اللغة العربية تُرس كمتطلب جامعي حتى في الاهدي التخصصات التي يتم التدريس فيها بلغة أخرى لتربه كمتطلب علمي لها. ج-مكون الأصل: لقد كان للانتماء إلى الأصل العربي دور كبير في تثكيل هوية الثخصية الوطنية للمجتمع

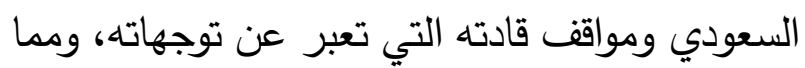
يؤكد الانتماء لهذا الأصل كلمة المؤسس رحمه الله" شعبنا العرب، فنحن من العرب وإليهم، وخدمة الإسلام والعرب واجبة علينا بصفة عامة، وخدمة شعبنا وأمتنا

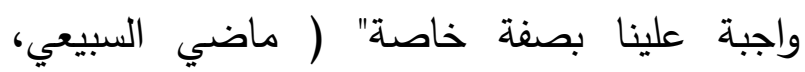




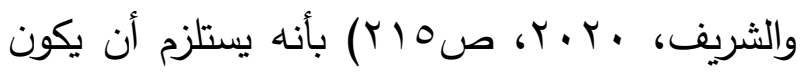

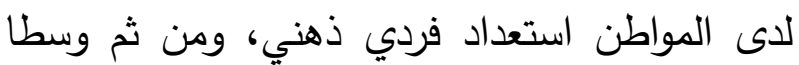
اجتماعيا يعزز هذا المفهوم، ويصقله في منطقة جغرافية تمثل الوطن له، حيث يكون لهذا الوطن ثقافة لهن

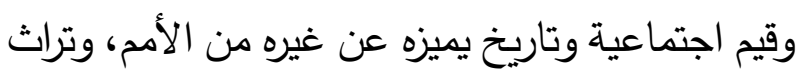
ينبثق من ذلك التاريخ ويرتبط به. r- مقومات الثخصية السعودية إن هوية الثخصية الوطنية تعد نتاج مجموعة من المقومات التي تختلف من مجتمع لآخر، والثخصية السعودية ارتكزت على مقومات كانت بمثابة القواسم المشتركة التي جمعت الشعب السعودي في كيان واحد ظهر وبرز كعلامة فارقة في محيطه الإقليمي. وتتمثل هذه المقومات فيما يلي: 1. وحدة الدين واللفة: يمثل المعتقد الواحد والمشترك

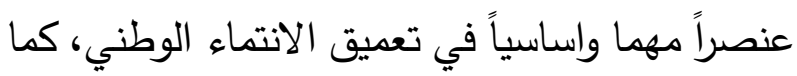
إن الانتماء لدين واحد تحت إمارة إمام واحد له في الرقاب بيعة يولا هذا كله الشعور بالوحدة بين أفراد الثاد الدولة، كما أن لوحدة اللغة في المملكة -لغة القرآن-

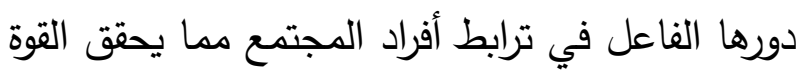

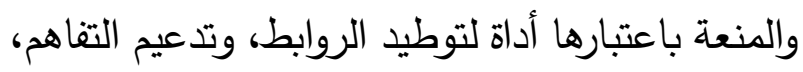

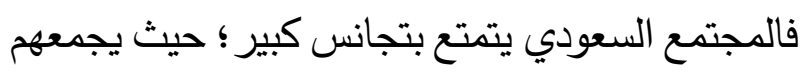

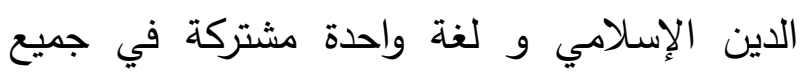
تعاملاتهم هي اللغة العربية، مما يساعد في الاتجاه نحو تعزيز الثخصية الوطنية. r. القيم الإسلامية: يهتم الشعب السعودي بالقيم لـنية على مختلف مجالاتها ومستوياتها ويعلي من شأنها
هـ -المكون الثقافي: ثمة علاقة وثيقة بين الثقافة وهوية الثخصية الوطنية؛ فما من هوية إلا وتختزل ثقافة، وقد تتعدد الثقافات في الهوية الواحدة، فالهوية الإسلامية يندرج تحتها ثقافات متعددة من ثقافات الأمم

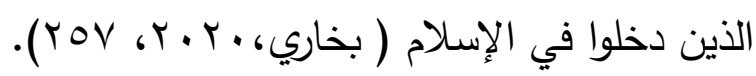

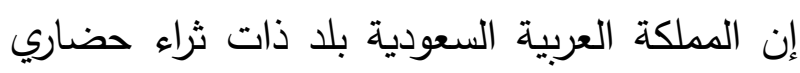
وتاريخي كبير، فهي مهد الحضارات المختلفة قبل الإسلام، كما أنها مهبط الوحي وقبلة المسلمين، ولا شك أنها قلب العروبة وأرض بطولات العرب شعرا

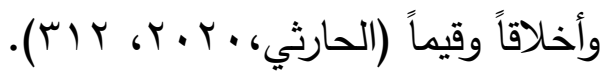
يمثل المكون الثقافي في هوية الثخصية السعودية إرثاً ضخماً؛ حيث أسهمت المكونات السابقة من دين هوبه إسلامي ولغة عربية وأصل عربي ممتد وموقع جغرافي متميز في اكتساب الشخصية السعودية ثقافة ذات صبغة إسلامية عربية أصيلة( ماضي السبيعي،

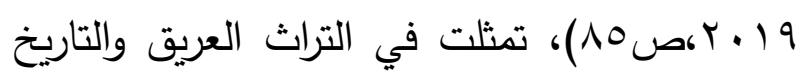

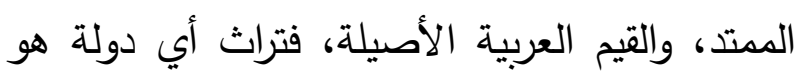

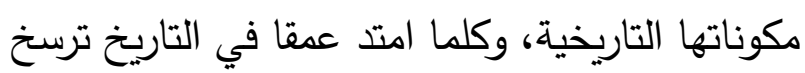
وجودها وهويتها، فأضحت تلك القيم والمثل والعادات والتقاليد والأعراف الناتجة عن تفاعل تلك المكونات تمثل الضوابط والمحددات للمجتمع السعودي وتتعكس على شخصية مواطنيه عبر ممارستهم لها في سلوكيات حياتهم الفردية والجماعية. من خلال النظر في المكونات السابقة يتضح أن تبلور مفهوم الشخصية الوطنية عن ذاتها وتشكيل الوعي بهويتها لا ينبني من فراغ، وهذا ما أكداه (الروقي 
ع. تقارب العادات والأعراف والتقاليد: إن تقارب عادات أفراد الشعب السعودي برغم اتساع الرقعة الجغرافية وتباين مناطقها، أحدث تجانساً بينهم مما أثر الثردي في تقوية الروابط بينهم، إضافة إلى الأعراف التي

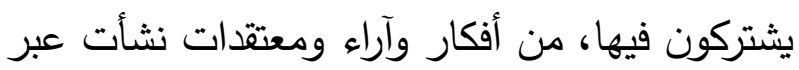
تاريخهم المشترك، ويخضع لها الأفراد في فكرهم

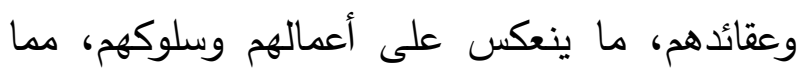
يسهم في تعزيز الثخصية الوطنية لديهم.

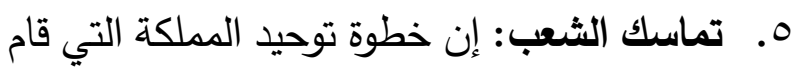
بها المؤسس الملك عبد العزيز -رحمه الله-وتوطين الهجر ، كان لها الأثر في بناء المجتمع السياسي الذي لهي

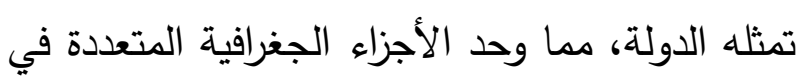
كل واحد يعلو ويسمو ويعلو على هذه الأجزاء كيانا متكاملاً مستقراً، اجتمع حوله كل أبناء الجزيرة العربية مما جعل انتمائهر لله يعلوا على انتمائهم التبلي والمحلي الضيق، مما أسهم في التماسك الاجتماعي بين أفراد الشعب وساهم في تكوين هويتهم الوطنية

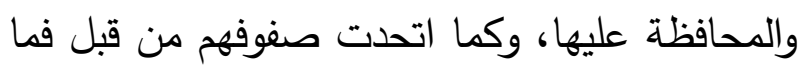

زالت متحدة لمواجهة مهددات الشخصية السعودية.

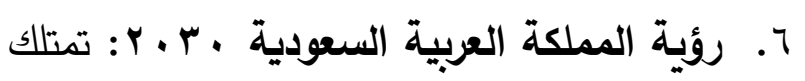
المملكة العربية والسعودية حاضراً محفزاً يتمثل في ماني الثروات الطبيعية والبشرية، وتسعى للتخطيط والتمكن من المستقبل عبر رؤية المملكة • • • r، فقد تم اعتماد الرؤية من قِبل أعلى السلطات الحكومية، واحتوت لهوته

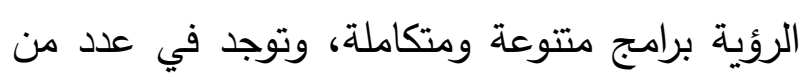

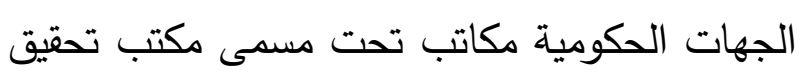

ويحافظ عليها، وإن حفاظ أي مجتمع على قيمه هو المؤشر الذي يكثف عن ثبات المجتمع وقدرته على ولى على على

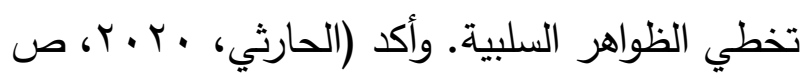
9. الإسلامية وما تحمله من قيم الوسطية والتسامح والعدالة والثفافية والانضباط والإتقان بالإضافة لما لماليه

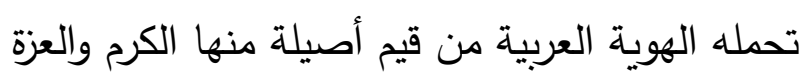

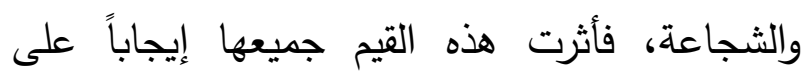
الثخصية السعودية وجعلت منها شخصية فريدة وقدوة لغيرها، وحتى مع تبدل ترتيب القيم في النسق القيمي

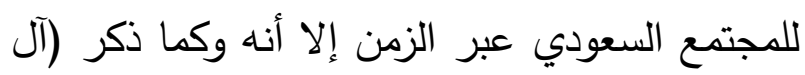

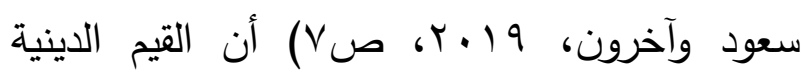
حافظت على الترتيب الأول حتى الآن.

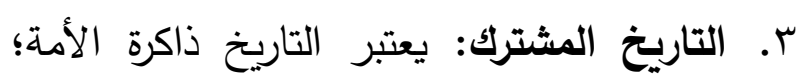
فتاريخ أي مجتمع يعد بمثابة ذاكرته وشعوره بذاته،

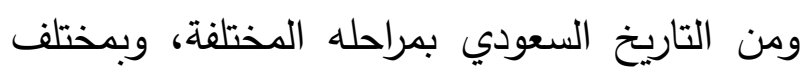

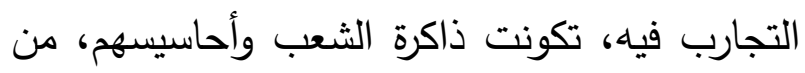
خلال ذكرياته وأحداثه فالذكريات التاريخية واستعادتها تساعد على تقريب النفوس، وتوحيد الصفوف لمواجهة

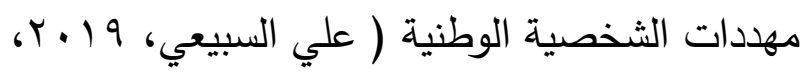
ص9 (1) ). وإن في تعريف الناشئة بتاريخ وطنهم وما مر به من انكسارات وانتصارات، وكيف تعامل أبناء الوطن معها انعكاساته على تكوين ذاكرتهم الوطنية،

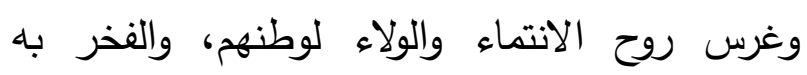

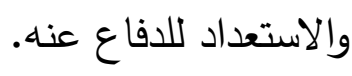


نحو النجاح والتفاؤل، وتكوين جيل يتماشى مع توجه

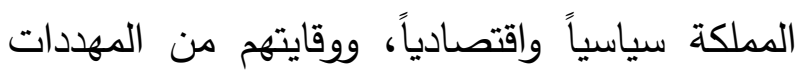

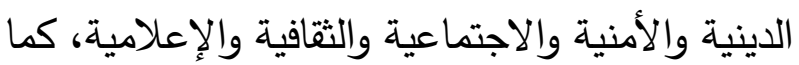
سيلعب دوراً بارزاً في تصحيح الصورة الذهنية للمملكة

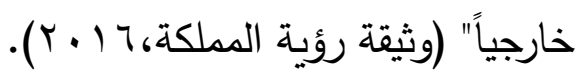

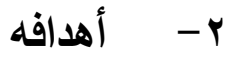

حددت وثقة رؤية المملكة العربية السعودية .r.r

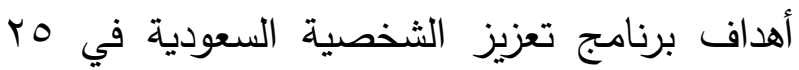

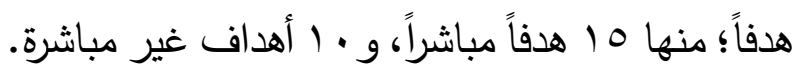
والأهداف المباشرة كما جاءت في بطاقة وصف

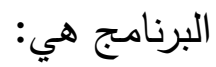
ترسيخ قيم التسامح والوسطية والعدل بالإضافة للشفافية والمثابرة، تعزيز الانتماء للوطن، التحصن من

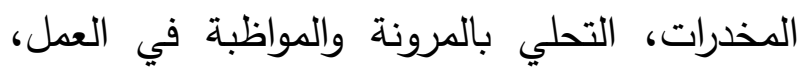
الحصول على العمل بنسب متكافئة، تمكين الثباب من الدخول لسوق العمل، الاهتمام بجانب التدريب

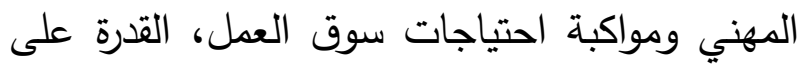

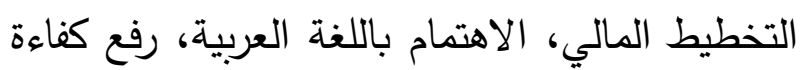
المؤسسات التعليمية، الارتقاء بمخرجات التعليم، التهاء

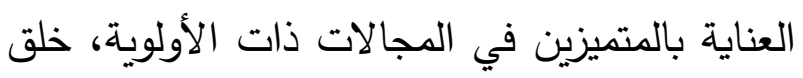
التوازن بين ما يخرجه التعليم وما يحتاجه سوق العمل، لئل تطوير التعليم ليصبح منظومة متكاملة، الارتقاء بترتيب المؤسسات التعليمية السعودية(وثيقة رؤية

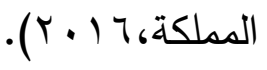

رؤية المملكة • •r.r، ومن بين البرامج الاستراتيجية في الرؤية برنامج تعزيز الثخصية السعودية. ثانيا/ برنامج تعزيز الشخصية السعودية في رؤية

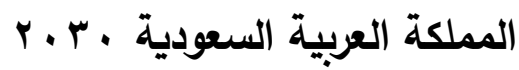
نظراً لأهمية الثخصية الوطنية باعتبارها محور التنمية وهدفها وأداتها في الوقت ذاته، عمدت رؤية المملكة العربية السعودية إلى تخصيص برنامج من برامجها الاستراتيجية لتعزيز الشخصية الوطنية. ويجدر بالباحثة أن تلقي الضوء على برنامج تعزيز الثخصية السعودية؛ حيث إن البحث الحالي معني بتقديم المنطلبات التربوية لتعزيز الثخصية السعودية

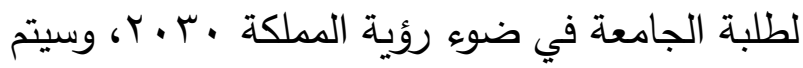
بناء المتطلبات التربوية وفق ما جاء في وصف هذا

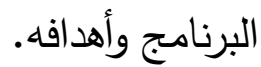
هو أحد البرامج التي أطلقها مجلس الثؤون الاقتصادية والتتمية، وهو ضمن ثلاثة عشرة برنامجاً تم طرحها كمبادرة تسهم في تحقيق رؤية المملكة العربية السعودية • ·.r.r، يشرف مجلس الثؤون الاقتصادية والتتمية على تتفيذها ومراقبة تحقيقها بحلول عام . $r$ r. r.

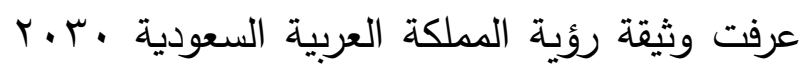
برنامج تعزيز الشخصية السعودية بأنه "برنامج لتنمية

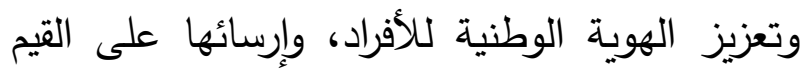
الإسلامية والوطنية، وتعزيز الخصائص الثخصية والنفسية التي من شأنها قيادة وتحفيز الأفراد وتقودهم 
يحفظ للمجتمع بقائه واستمراريته وخصوصيته، فلا

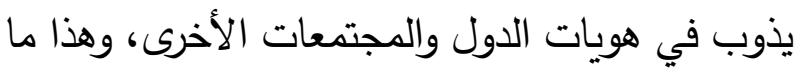

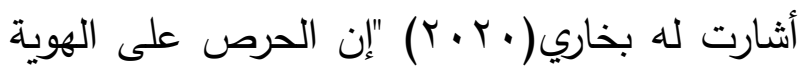

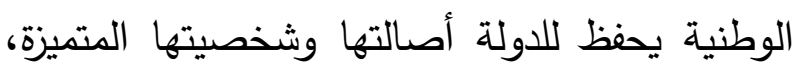
ويقيها من الهزيمة الداخلية تجاه المجتمعات المخالفة، فلا تذوب فيها ولا تتشبه بها فيما هو من خصائصها

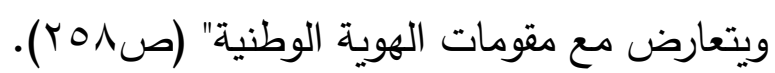
لذا فإن من المهم تعزيز الهوية الوطنية في الثخصية السعودية بعامة وطلبة الجامعة بخاصة، من خلال

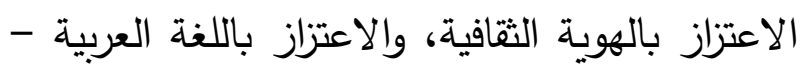

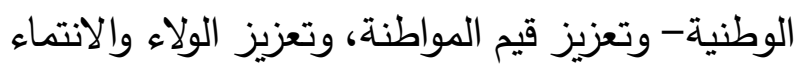

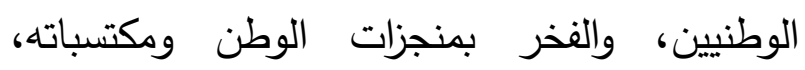
والتمسك بأعراف المجتمع وتقاليده، مما يسهم بالرفع من مستوى الهوية للدرجة التي تستطيع الصمود الإيجابي المملوء بالثقة بالنفس والاعتزاز بالهوية

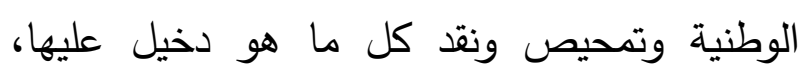
متجاوزة مخاطر العولمة الثقافية. ب- البعد القيمي (المتمثل في تعزيز القيم الإسلامية والوطنية): تُعرف القيم بأنها "مجموعة من الأحكام المعيارية بمضامين واقعية، تنال قبولاً من جماعة اجتماعية معينة حتى تتجسد في سياقات الفرد السلوكية واللفظية واتجاهاته واهتماماته، وتتسم القيم بمستوى عالٍ من لندين

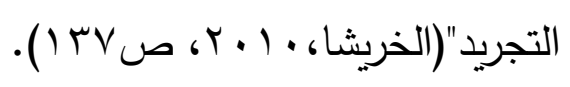

هذا وتحتل القيم مكانة مهمة في البنية الثقافية والحضارية في المجتمعات؛ بوصفها بصمة الهوية r- أبعاد تعزيز الثخصية السعودية المتضمنة في وصف البرنامج من خلال ما جاء في تعريف برنامج تعزيز الشخصية

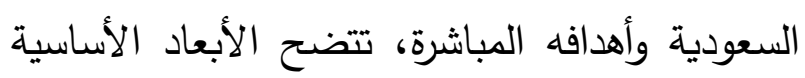
لتعزيز الثخصية السعودية والتي تم الاعتماد عليها في البحث الحالي لتحديد المتطلبات التربوية لتعزيز

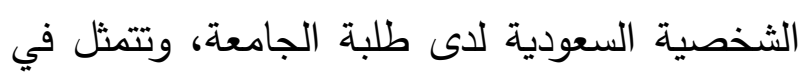

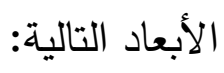

أ- البعد الوطني (المتمثل في تعزيز الهوية الوطنية):

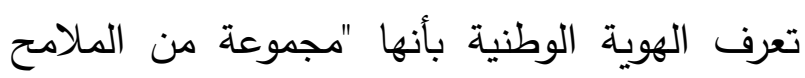
الثقافية الخاصة بمجتمع معين يميزه عن غيره من لن لهن المجتمعات، وهي الإطار المشترك الذي يجمع أبناء

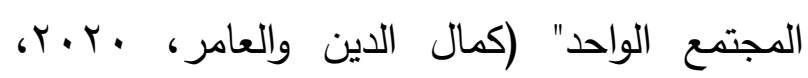

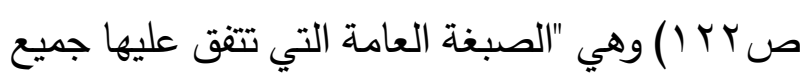

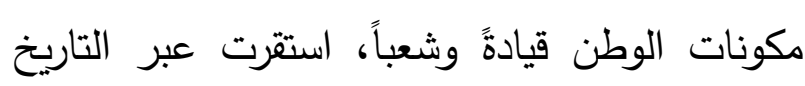

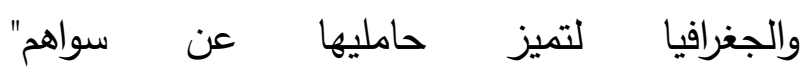

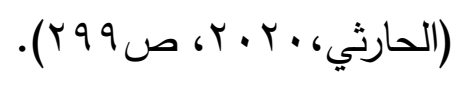

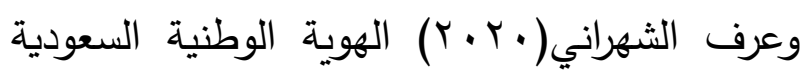
بأنها مجموعة من الصفات والخصائص والقواسم المشتركة التي يتميز بها المجتمع في المملكة العربية السعودية وتميزه عن غيره من المجتمعات، وتميز

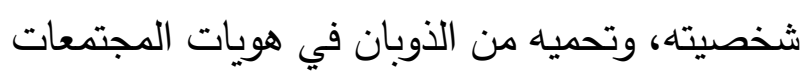

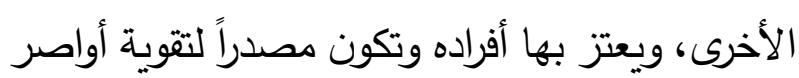

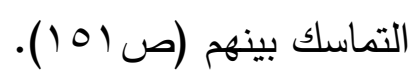
وتمثل الهوية الوطنية لأي مجتمع العمود الفقري الذي لـي يقوم عليه كيانه، وإن التمسك بمقومات تلك الهوية 
ج-البعد الشخصي والنفسي (المتمثل في تعزيز الخصائص الثخصية والنفسية) الشخصية هي المكون الافتراضي الداخلي والذي يحدد

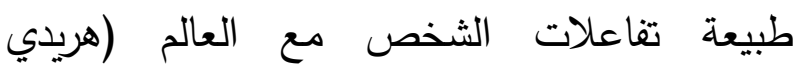

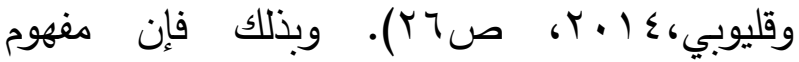
الخصائص الشخصية والنفسية يعبر عما تتسم به الشخصية الإنسانية داخل تكوين الشخص الجسدي والنفسي، حيث تمثل هذه الخصائص أنماط سلوكه،

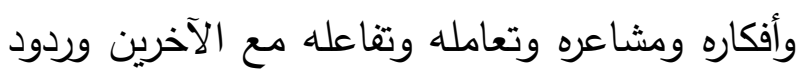
فعله تجاههم. إن الثخصية السعودية بناء على ما تم ذكره في مكوناتها ومقوماتها تتمتع بخصائص تجعلها شخصية متفردة عن غيرها، مما يستدعي التركيز على هذه الخصائص وتعزيزها بكل ما من شأنه الحفاظ عليها كثخصية إيجابية معتزة بذاتها وبدينها وقيمها، متزنة نفسيا وفكريا، ودعم كل ما يقودها نحو التفاؤل والنجاح والإبداع، ما ينعكس على سلوكها الظاهر ويجعلها صورة مشرقة مشرفة تعكس صورة المواطن السعودي

$$
\text { في كافة أرجاء العالم. }
$$

ومن الأهية بمكان التركيز على الخصائص التصان الشخصية والنفسية لطلبة الجامعة، إذ يمتد دور الجامعة التعليمي والتربوي إلى بناء شخصية الطالب

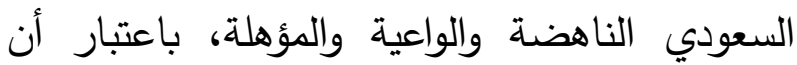

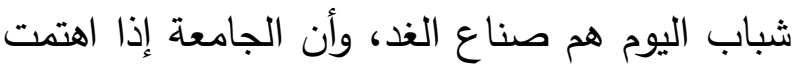

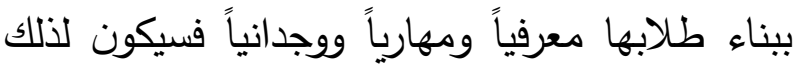
انعكاساته الإيجابية على خصائصهم الشخصية والنفسية، ومن ثم على المجتمع الذي سيتقدون
للمجتمع وأساس أي إصلاح تربوي فيه، كما أن الحفاظ على قيم المجتمع هو المؤشر الذي يكثف عن ثبات المجتمع وقدرته على تخطي الظواهر السلبية والتيارات

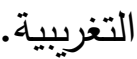
والقيم الإسلامية والوطنية تعد مرتكزاً مهماً في المجتمع السعودي، كونها نابعة من الدين الإسلامي الحنيف الذي هو منهاج الحياة وأساس الحكم والتعاملات والمعاملات في المملكة العربية السعودية، تلك القيم هي التي أطرت المجتمع وأكسبته هويته، بحفاظه على

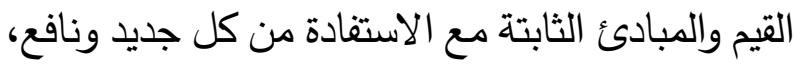
فلكل أمة قيمها الثابتة التي لا يمكن أن تحقق التتمية التحنية المستدامة الثاملة لها في غياب منظومة تلك القيم، ومن حق كل شعب أن يعتز بقيمه ومبادئه التي يقوم عليها كيانه وتميزه عن غيره. مما يستدعي تتميتها وتدعيمها في شخصية أبناء الوطن في جميع المراحل، وخاصة طلبة الجامعات فهناك انشغال واضح في المجتمع السعودي كغيره من المجتمعات الإسلامية والعربية بمضمون ثقافة الشباب

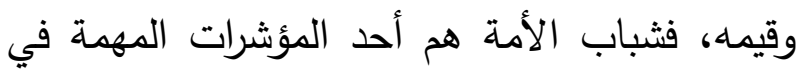
دراسة مركز ثقلها الحضاري، وأحد أهم الدعائم في بنية الرصيد الاستراتيجي لحركة التتمية فيها.

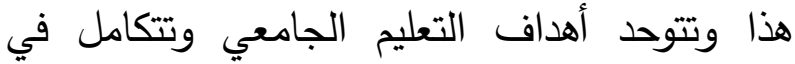
نشاطاتها لنُخرج نخبة متعلمة تتمتع بقدر من الحكمة والمسؤولية الأخلاقية وتتميز بنسق قيمي متتاغم مع من لهن أهداف المجتمع وغاياته ومتوافقاً مع توجه رؤية

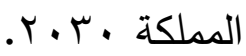


واشتملت الاستبانة على قسمين؛ الأول منها عبارة عن البيانات الأولية للمستجيب (الجنس، القسم، الدرجة

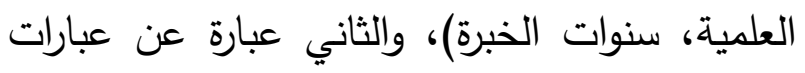
الاستبانة موزعة على ثلاثة أبعاد؛ البعد الأول: تعزيز

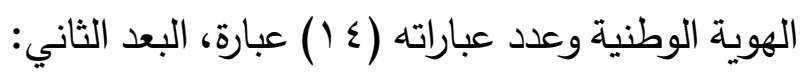
تعزيز القيم الإسلامية والوطنية، وعدد عباراته (T) عبارة، البعد الثالث: تعزيز الخصائص الثخصية

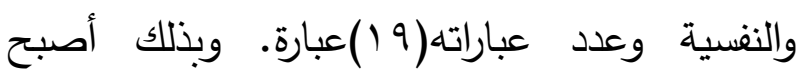

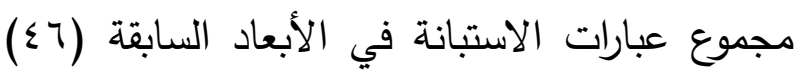

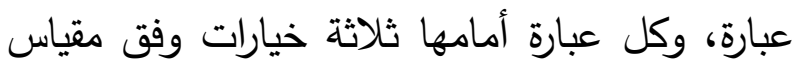

$$
\begin{aligned}
& \text { متدرج (موافق - محايد- غير موافق). } \\
& \text { صدق وثبات أداة البحث } \\
& \text { أ-صدق الأداة }
\end{aligned}
$$

بعد إعداد أداة البحث (الاستبانة) من قبل الباحثة

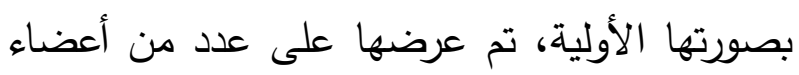

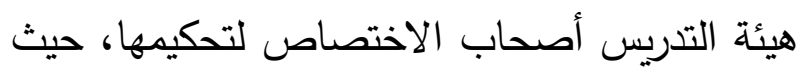
أبدوا أراءهم حول الاستبانة من حيث تعلق فقراتها

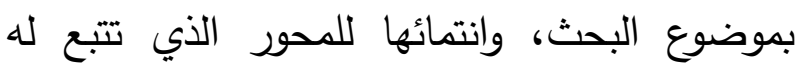

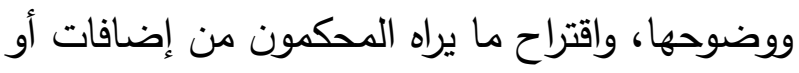
تعديل، وتم الأخذ بالملاحظات والتوصيات، حتى منى من إهن

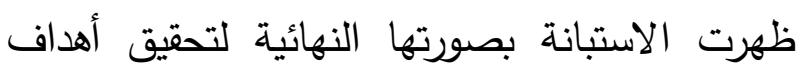

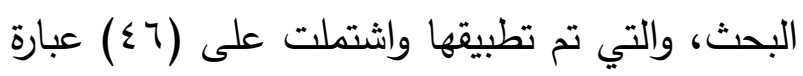

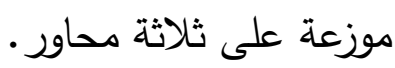
ولمعرفة صدق الاتساق الداخلي لفقرات الأبعاد تم حساب الارتباط بين كل فقرة وبعدها، وكذلك بين الفقرة والأداة ككل كما في الجدول التالي:
وظائفه فيه بعد تخرجه مما يحقق التتمية الثاملة

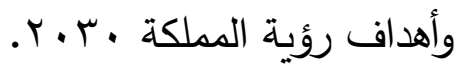
منهجية البحث واجراء اته منهج البحث اتبعت الباحثة المنهج الوصفي التحليلي وهو المنهج الأنسب لتحقيق أهداف البحث الحالي، لكونه أحد أشكال التحليل والتقسير العلمي المنظم لوصف ظاهرة

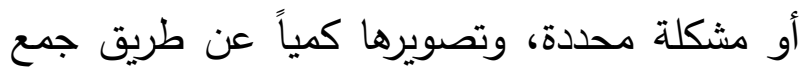
بيانات ومعلومات مقننة عنها، وتصنيفها، وتحليلها، وإخضاعها للدراسة الدقيقة، وهو ما تم القيام به لتحديد المتطلبات التربوية لتعزيز الشخصية السعودية لطلبة

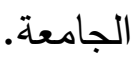
مجتمع البحث تكون مجتمع البحث من جميع أعضاء هيئة التدريس

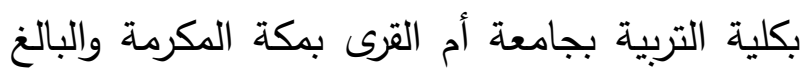
عددهم (Y Y Y ) عضواً، وقد تم تعميم استبانة الكترونية على جميع الأعضاء عبر برنامج مسار للاتصالات

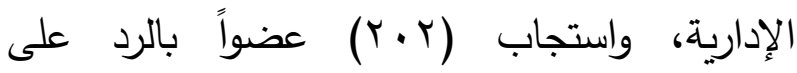

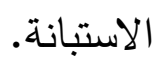

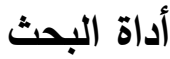
تم إعداد استبانة بالمتطلبات التربوية لتعزيز الثخصية السعودية لطلبة الجامعة في ضوء بؤية بالبة المملكة

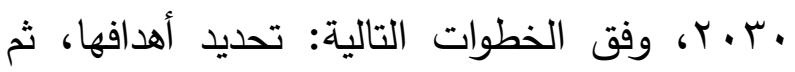
تحديد مصادر بناء قائمة المتطلبات التربوية وهي:

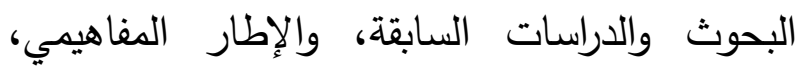
ووصف وأهداف برنامج تعزيز الثخصية السعودية في

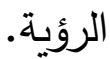




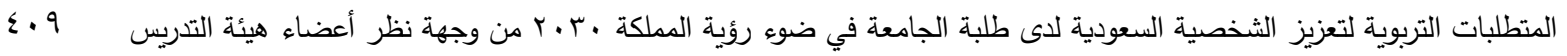

جدول (1) يوضح معامل الارتباط بين الفقرات وأبعادها وكذلك بين الفقرات والأداة

\begin{tabular}{|c|c|c|c|c|c|c|c|c|}
\hline & \multicolumn{2}{|c|}{ البعد الثالث } & \multicolumn{3}{|c|}{ البعد الثاني } & \multicolumn{3}{|c|}{ البعد الأول } \\
\hline معامل & معامل & & معامل & معامل & & معامل & معامل & \\
\hline الارتباط & الارتباط & رقم الفقرة & الارتباط & الارتباط & رقم & الارتباط & الارتباط & رقم \\
\hline بالأداة & بالبعد & & بالأداة & بالبعد & الفقرة & بالأداة & بالبعد & الفقرة \\
\hline $.766^{* * *}$ & $.756^{* *}$ & 28 & $.491^{* *}$ & $.506^{* * *}$ & 15 & $.563^{* *}$ & $.616^{* * *}$ & 1 \\
\hline $.821^{* * *}$ & $.712^{* * *}$ & 29 & $.724^{* * *}$ & $.795^{* * *}$ & 16 & $.600^{* * *}$ & $.702^{* * *}$ & 2 \\
\hline $.793^{* * *}$ & $.694^{* * *}$ & 30 & $.221^{* *}$ & $.272^{* * *}$ & 17 & $.568^{* * *}$ & $.602^{* * *}$ & 3 \\
\hline $.514^{* * *}$ & $.608^{* * *}$ & 32 & $.695^{* * *}$ & $.780^{*}$ & 18 & $.448^{* * *}$ & $.483^{* * *}$ & 4 \\
\hline $.569^{* * *}$ & $.640^{* *}$ & 32 & $.502^{* * *}$ & $.604^{* * *}$ & 19 & $.492^{* * *}$ & $.389^{* * *}$ & 5 \\
\hline $.569^{* * *}$ & $.640^{* *}$ & 33 & $.576^{* *}$ & $.604^{* * *}$ & 20 & $.390^{* * *}$ & $.557^{* *}$ & 6 \\
\hline $.571^{* * *}$ & $.694^{* * *}$ & 34 & $.653^{* * *}$ & $.599^{* * *}$ & 21 & $.617^{* * *}$ & $.714^{* * *}$ & 7 \\
\hline $.484^{* * *}$ & $.628^{* *}$ & 35 & $.600^{* * *}$ & $.565^{* * *}$ & 22 & $.600^{* * *}$ & $.702^{* * *}$ & 8 \\
\hline $.458^{* * *}$ & $.554^{* * *}$ & 36 & $.515^{* *}$ & $.506^{* * *}$ & 23 & $.600^{* * *}$ & $.702^{* * *}$ & 9 \\
\hline $.517^{* * *}$ & $.570^{* * *}$ & 37 & $.821^{* * *}$ & $.878^{* * *}$ & 24 & $.733^{* * *}$ & $.608^{* * *}$ & 10 \\
\hline $.739^{* * *}$ & $.789^{* * *}$ & 38 & $.737^{* * *}$ & $.807^{* * *}$ & 25 & $.444^{* *}$ & $.667^{* * *}$ & 11 \\
\hline $.562^{* * *}$ & $.681^{* * *}$ & 39 & $.752^{* *}$ & $.822^{* * *}$ & 26 & .082 & $.190^{* *}$ & 12 \\
\hline $.821^{* * *}$ & $.712^{* * *}$ & 40 & $.793^{* *}$ & $.848^{* * *}$ & 27 & $.416^{* *}$ & $.510^{* *}$ & 13 \\
\hline $.749^{* * *}$ & $.719^{* *}$ & 41 & & & & $.600^{* * *}$ & $.702^{* * *}$ & 14 \\
\hline $.832^{* * *}$ & $.725^{* * *}$ & 42 & & & & & & \\
\hline $.677^{* * *}$ & $.780^{* *}$ & 43 & & & & & & \\
\hline $.523^{* * *}$ & $.560^{* * *}$ & 44 & & & & & & \\
\hline $.465^{* * *}$ & $.469^{* * *}$ & 45 & & & & & & \\
\hline $.727^{* * *}$ & $.651^{* * *}$ & 46 & & & & & & \\
\hline
\end{tabular}

** دال عند ا.,.,

يتضح من الجدول السابق أن جميع الفقرات دالة عند مستوى الدلالة ا .,. • مما يعني أن جميع الفقرات مرتبطة بالبعد الخاص بها وكذلك بالأداة ككل ويدل ذلك على صدق الفقرات. ولمعرفة صدق الأبعاد مع الأداة ككل تم احتساب قيمة الارتباط بين الأبعاد والأداة كما في الجدول التالي: 


$$
\text { أماني محمد بن محمد قليوبي }
$$

جدول (ץ) يوضح معاملات الارتباط بين الأبعاد الفرعية والدرجة الكلية للأبعاد

\begin{tabular}{|c|c|}
\hline | معامل الارتباط بالدرجة الكلية & 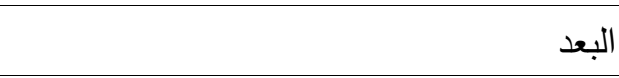 \\
\hline $.860 * *$ & الأول (تعزيز الهوية الوطنية) \\
\hline $.941 * *$ & الثاني (تعزيز القيم الإسلامية والوطنية) \\
\hline $.943 * *$ & الثالث (تعزيز الخصائص الثخصية والنفسية) \\
\hline
\end{tabular}

تبين من الجدول السابق أن جميع الأبعاد مرتبطة ألفا -كرونباخ (Cronbach's alpha)، الذي تتراوح بالأداة عند مستوى الدلالة (1 (., •)، وهذا يدل على قيمته بين الصفر والواحد الصحيح، وبصفة عامة كلما

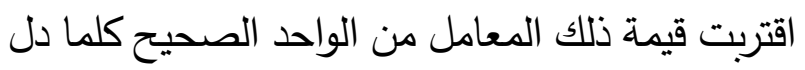
صدق الأداة للأبعاد كاملة. ذلك على ارتفاع درجة الاتساق الداخلي، أو الثبات ب-ثبات الأداة

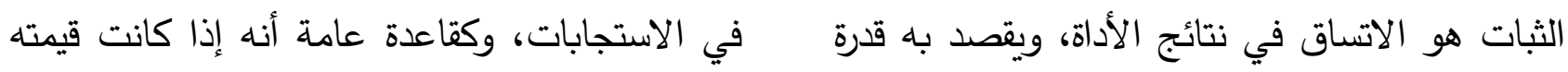

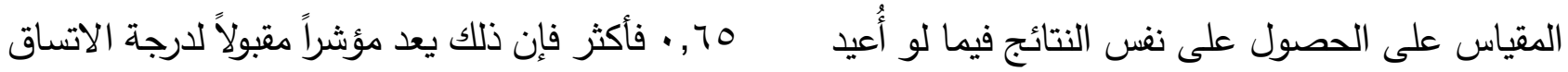

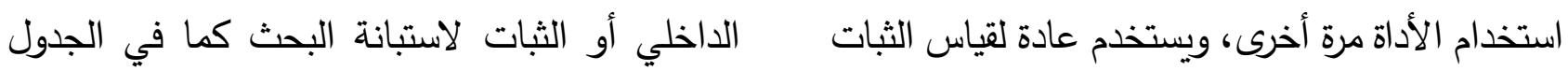
أحد المقاييس الإحصائية الثهيرة يُطلق عليه مُعامل التالي: جدول (r) يوضح قيم معامل ألفا كرونباخ لكل بعد من أبعاد الاستبانة

\begin{tabular}{|c|c|c|}
\hline ألفا كرونباخ & الفقرات & البعد \\
\hline 0.761 & 14 & الأول (تعزيز الهوية الوطنية) \\
\hline 0.890 & 13 & الثاني (تعزيز القيم الإسلامية والوطنية) \\
\hline 0.917 & 19 & الثالث (تعزيز الخصائص الثخصية والنفسية) \\
\hline 0.917 & 46 & الأبعاد ككل (تعزيز الثخصية السعودية) \\
\hline
\end{tabular}

تبين من الجدول السابق أن المقياس يتمتع بدرجة الأساليب الإحصائية المستخدمة في التحليل عالية من الثبات، حيث إن جميع قيم ألفا مرتفعة في

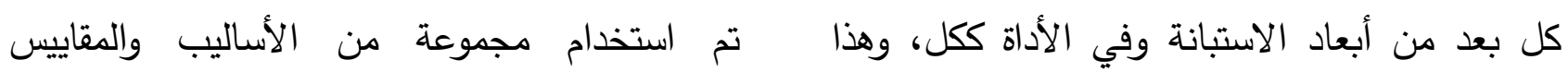
مؤشر للاتساق الداخلي ولثبات الاستبانة، مما يشير الاحصائية في المعالجات والتحليل الإحصائي هي:

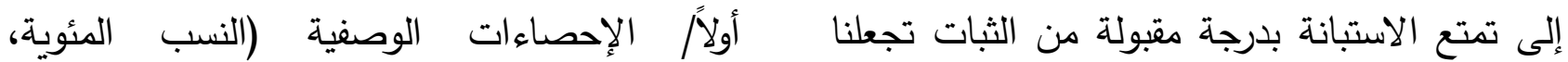
المتوسطات الحسابية والانحرافات المعيارية) 
ثانياً/ الإحصاء الاستدلالي (ارتباط سبيرمان، ت توزيع مجتمع البحث بعد التطبيق

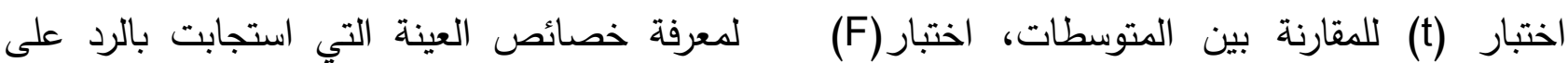
باستخدام التحليل التباين الأحادي (ANOVA)، الاستبانة، تم عمل جداول تلخص عدد كل خاصية اختبار توكي(Tukey) للمقارنة بين الفروق. ونسبتها المئوية كما في الجداول الآتية:

جدول (؛) يوضح توزيع أفراد العينة بحسب الجنس

\begin{tabular}{|c|c|c|}
\hline النسبة المئوية & العدد & الجنس \\
\hline$\% 38.6$ & 78 & ذكر \\
\hline$\% 61.4$ & 124 & أنثى \\
\hline$\% 100.0$ & 202 & المجموع \\
\hline
\end{tabular}

جدول (0) يوضح توزيع أفراد العينة بحسب الدرجة العلمية

\begin{tabular}{|c|c|c|}
\hline النسبة المئوية & العدد & الدرجة العلمية \\
\hline$\% 25.7$ & 52 & أستاذ \\
\hline$\% 35.6$ & 72 & أستاذ مساعد \\
\hline$\% 38.6$ & 78 & أستاذ مشارك \\
\hline$\% 100.0$ & 202 & المجموع \\
\hline
\end{tabular}

جدول (†) يوضح توزيع أفراد العينة بحسب القسم العلمي

\begin{tabular}{|c|c|c|}
\hline النسبة المئوية & العدد & القسم \\
\hline$\% 9.4$ & 19 & إدارة تربوية وتخطيط \\
\hline$\% 8.9$ & 18 & تربية أسرية \\
\hline$\% 17.3$ & 35 & تربية إسلامية ومقارنة \\
\hline$\% 12.9$ & 26 & تربية بلنية \\
\hline$\% 5.9$ & 12 & تربية خاصة \\
\hline$\% 4.0$ & 8 & طفولة مبكرة \\
\hline$\% 15.8$ & 32 & علم نفس \\
\hline$\% 25.7$ & 52 & مناهج وطرق تدريس \\
\hline$\% 100.0$ & 202 & المجموع \\
\hline
\end{tabular}


جدول (V) يوضح توزيع أفراد العينة بحسب سنوات الخبرة

\begin{tabular}{|c|c|c|}
\hline النسبة المئوية & العدد & سنوات الخبرة \\
\hline 12.4 & 25 & أقل من ه سنوات \\
\hline 18.3 & 37 & من ه إلى أقل ـ سنوات \\
\hline 69.3 & 140 & من ل 1 سنوات فأكثر \\
\hline 100.0 & 202 & المجموع \\
\hline
\end{tabular}

الوطنية لدى طلبة الجامعة وذلك من وجهة نظرهم في

نتائج الدراسة الميدانية وتفسيرها

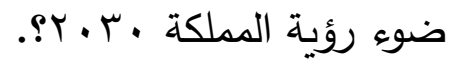

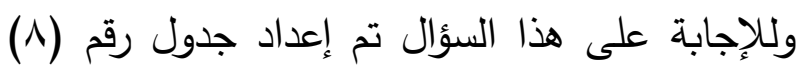

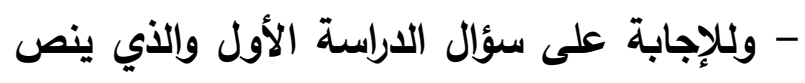

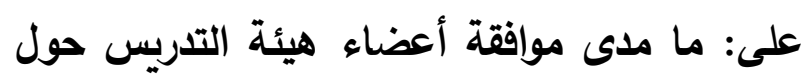
يحتوي على المتوسطات الحسابية والانحرافات المتطلبات التربوية لتعزيز الثخصية السعودية لاى مولى المعيارية وترتيب الفقرات وفق المتوسط الحسابي ودرجة تمثيلها حيث قسمت درجات الموافقة وفقا للمتوسط الحسابي وهي كالآتي

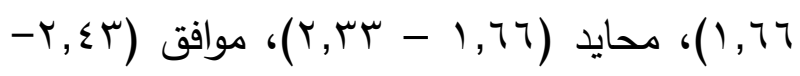
طلبة الجامعة من خلال تعزيز (الهوية الوطنية، القيم الإسلامية والوطنية، الخصائص الثخصية والنفسية) وذلك من وجهة نظرهم في ضوء رؤية المملكة

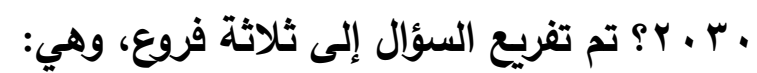
الفرع الأول من السؤال الأول: ما مدى موافقة أعضاء

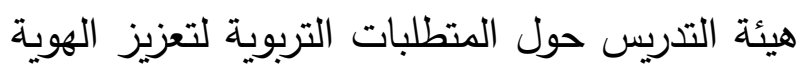
جدول (^) المتوسطات الحسابية والانحرافات المعيارية لكل فقرة من فقرات بعد (تعزيز الهوية الوطنية) مع رتبتها ودرجة تمثيلها

\begin{tabular}{|c|c|c|c|c|}
\hline ارتفّة & المعياري & الحستابي & الفقرات & الفقرة \\
\hline 1 & .070 & 3.00 & تتمية مشاعر الاعتزاز بالانتماء للوطن & 1 \\
\hline 2 & .000 & 3.00 & تعزيز روح الولاء للوطن والدفاع عن مقدساته & r \\
\hline 3 & .000 & 3.00 & التعرف على الحقوق والواجبات الوطنية & $r$ \\
\hline 4 & .000 & 3.00 & الاعتزاز بالهوية الإسلامية والوطنية والعربية & $\varepsilon$ \\
\hline 13 & .183 & 2.97 & تعلم آداب الشاركة في المناسبات الدينية والوطنية & o \\
\hline 14 & .388 & 2.85 & استخدام اللغة العربية الفصحى في كافة جوانب العملية التعليمية & 1 \\
\hline 10 & .172 & 2.98 & التعرف على خصائص المملكة الثرعية ومكانتها الحضارية & $\mathrm{v}$ \\
\hline 6 & .099 & 2.99 & التعرف على جهود المملكة في خدمة الإسلام وقضايا المسلمين & $\wedge$ \\
\hline 7 & .121 & 2.99 & التوعية بالأفكار الهذامة والإثاعات المغرضة التي تزعزع الوحدة الوطنية والأمن الوطني & 9 \\
\hline 8 & .121 & 2.99 & التمسك بالثوابت الدينية والمبادئ الوطنية & 1. \\
\hline 11 & .172 & 2.98 & التعرف على دور المملكة القيادي في نشر السلام & 11 \\
\hline
\end{tabular}




\begin{tabular}{|c|c|c|c|c|}
\hline 9 & .121 & 2.99 & الوعي بالتحديات والمشكلات التي تواجه & IT \\
\hline 12 & .140 & 2.98 & التعريف بتراث الوطن وأهم احداثه التاريخية & 14 \\
\hline 5 & .000 & 3.00 & تتمية مشاعر الفخر والاعتزاز بالمنجزات الوطنية & $1 \varepsilon$ \\
\hline & .05766 & 2.9781 & \multicolumn{2}{|c|}{ تعزيز الهوية الوطنية } \\
\hline
\end{tabular}

والواجبات الوطنية يكوّن الوعي بمفهوم المواطنة التي تعتبر مرتكز أساس في الهوية الوطنية، ولعل لهذه الاعتبارات أهمية من وجهة نظر عينة البحث عن بقية الفقرات الأخرى مما جعلها تتقدم عنها. أما الفقرة التي كان ترتيبها الأخير فهي الفقرة رقم (ج) والتي تتص على (استخدام اللغة العربية الفصحى في كافة جوانب العملية التعليمية) بمتوسط حسابي

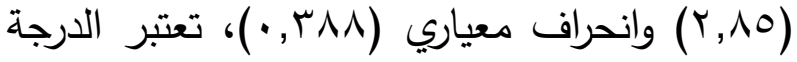
مرتفعة إلا أن ترتيبها كان الأخير من بين فقرات البعد، ولعل ذلك يعود إلى تركيز عينة البحث على الفقرات ذات الارتباط الظاهر والمباشر بالهوية الوطنية، ولأن العبارة ربطت بين استخدام اللغة الفصحى بكافة جوانب العملية التعليمية والتي نلحظ انحساراً كبيراً لها في الواقع التعليمي خاصة من قِبل الطلبة. الفرع الثاني من السؤال الأول: ما مدى موافقة أعضاء هيئة التدريس حول المتطلبات التربوية لتعزيز (القيم الاسلامية الوطنية) لاى طلبة الجامعة وذلك من وجهة نظرهم في ضوء رؤية المملكة . . Y. وللإجابة على هذا السؤال تم إعداد الجدول التالي:
من الجدول السابق تبين أن متوسط أبعاد المتطلبات التربويـة لتعزيز الهوية الوطنية كان مرتفعا بمتوسط

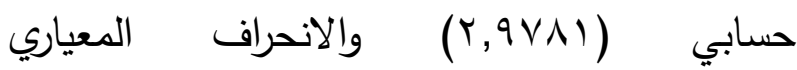
( بدرجة موافق، حيث كانت الفقرات الأعلى في البعد

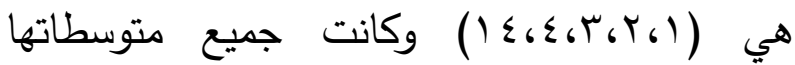
(ب, (r)، وتتص هذه الفقرات على (تنمية مشاعر الاعتزاز بالانتماء للوطن) بانحراف معياري

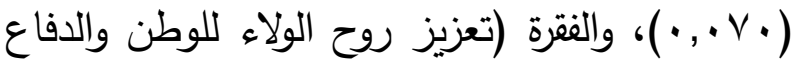
عن مقدساته) بانحراف معياري ( (·.,·)، والفقرة (التعرف على الحقوق والواجبات الوطنية) بانحراف معياري ( · , •)، والفترة (الاعتزاز بالهوية الإسلامية والوطنية والعربية) بانحراف معياري ( · ., •)، والفقرة (تنمية مشاعر الفخر والاعتزاز بالمنجزات الوطنية) بانحراف معياري ( (·, ·)،إن الموافقة على جميع فقرات البعد تؤكد أهمية المتطلبات التربوية التي اشتمل عليها، وتقسر الباحثة بأن الفقرات السابقة جاءت في الرتب الأعلى كون الانتماء والولاء الوطنيين من المرتكزات الأساسية في تعزيز الهوية الوطنية إضافة لكون تتمية مشاعر الفخر والاعتزاز بالمنجزات الوطنية يزيد من هذين المرتكزين وينميهما، كما أن الاعتزاز بالهوية الإسلامية والعربية يعتبر أصلاً يتغرع عنه الاعتزاز بالوطن، كما أن التعرف على الحقوق 
جدول (9) يوضح المتوسطات الحسابية والانحرافات المعيارية لكل فقرة من فقرات بعد (تعزيز القيم الإسلامية الوطنية) مع رتبتها ودرجة تمثيلها

\begin{tabular}{|c|c|c|c|c|}
\hline رتبقة & 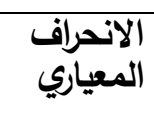 & المستوسطي المسبي & 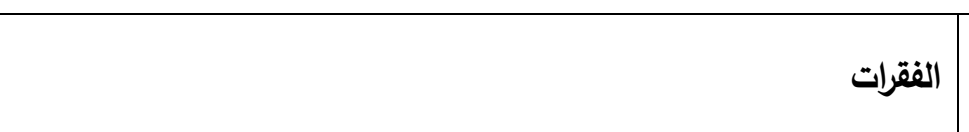 & راقفرة \\
\hline 8 & .165 & 2.98 & تعزيز روح التعاون والعمل بروح الفريق & 10 \\
\hline 3 & .121 & 2.99 & نشر ثقافة التسامح بين الطلبة مع بعضهم ومع الأخرين & 17 \\
\hline 4 & .121 & 2.99 & مواكبة المستجدات والتغييرات الاجتماعية في ظل مبادئ وقيم الإسلام & IV \\
\hline 2 & .099 & 2.99 & التوعية بالمخاطر الناجمة عن التقنيات الحديثة وآثارها القيمية والأخلاقية & 11 \\
\hline 9 & .156 & 2.98 & تهيئة مناخ من العدالة والمساواة بين أفراد المجتمع الجامعي & 19 \\
\hline 10 & .156 & 2.98 & تجسيد مفهوم الوسطية قولا وعملا في كافة التعاملات & r. \\
\hline 13 & .209 & 2.97 & تقبل الرأي الأخر وفق الضوابط الثرعية والأخلاقية & Y) \\
\hline 1 & .000 & 3.00 & ترسيخ القيمئولإلنسانية، العدالة الاجتماعية). & rr \\
\hline 5 & .099 & 2.99 & 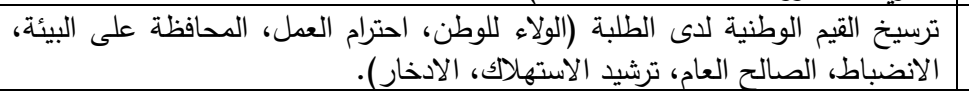 & rT \\
\hline 6 & .121 & 2.99 & ترسيخ التيم الاجتماعية لاى الطلبة مثل (الأمانة، الصداقة، الأخوة، احترام الأخرين، & $r \varepsilon$ \\
\hline 11 & .140 & 2.98 & 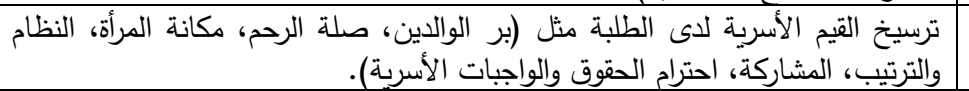 & ro \\
\hline 7 & .121 & 2.99 & 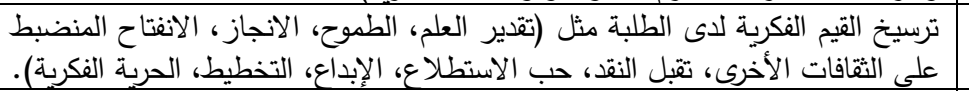 & $r 7$ \\
\hline 12 & .156 & 2.98 & تعزيز قيم الالتزام والإيجابية نحو العمل والإنتاج بكافة صوره ع & TV \\
\hline & .08085 & 2.9821 & \multicolumn{2}{|c|}{ تعزيز القيم الإسلامية والوطنية } \\
\hline
\end{tabular}

التثرقة، نبذ العنف، العنصرية، الحرية، العدالة

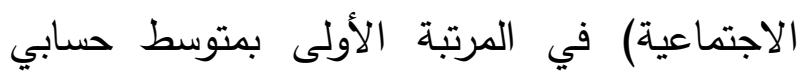
(ץ) ملحة لها في هذه المرحلة العمرية وتحديداً في الفترة الحالية التي يعتبر التطرف والتعصب والإرهاب من فئن أكثر مهددات الهوية الوطنية، وتبعتها في الترتيب الفقرة رقم (1) ( ) والتي تنص على (التوعية بالمخاطر الناجمة عن التقنيات الحديثة وآثارها القيمية
من الجدول السابق تبين أن متوسط المتطلبات التربوية

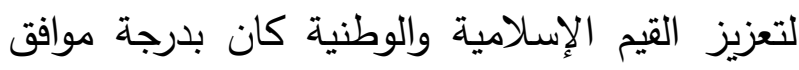

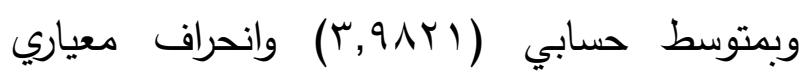
(1.10 •., , )، وبالنسبة لفقرات البعد كانت جميعها بدرجة موافق، وتفسر الباحثة الموافقة على جميع

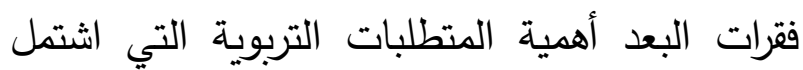
عليها، وقد جاءت الفقرة رقم (Yr) والتي تتص على التى (ترسيخ القيم الإنسانية لدى الطلبة مثل : السلام، نبذ لبد 
مما يشير إلى أن تقبل الرأي الآخر وفق الضوابط

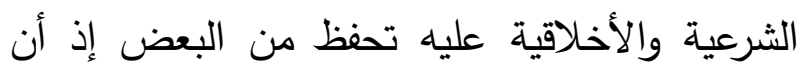

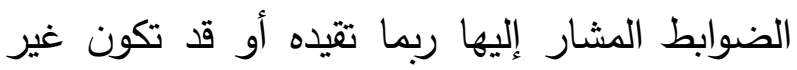
معلومة لدى الطلبة ويجب التعريف بها.

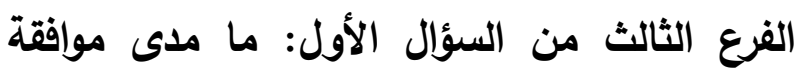
أعضاء هيئة التدريس حول المتطلبات التربوية لتعزيز (الخصائص الثخصية و النفسية) لاى طلبة الجامعة وذلك من وجهة نظرهم في ضوء رؤية

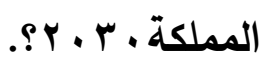
وللإجابة على هذا السؤال تم إعداد الجدول التالي:
والأخلاقية) بمتوسط حسابي (Y,99) و انحراف معياري (99 •., •)، وقد اقتضت أن تكون التوعية بها من الأولويات التي يتم الاتفاق عليها؛ لما تمثله تلك ولك المخاطر من مهددات على البناء القيمي والأخلاقي للأفراد وخاصة الثباب الذين يمثلون الثريحة التي مليدي يتتاولها البحث مما ينعكس على شخصياتهم، فكانت

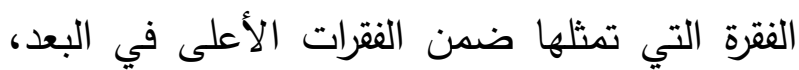

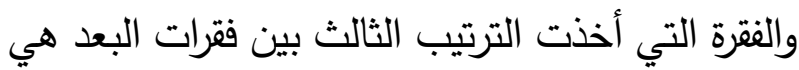
الفقرة رقم (7 (1) والتي تتص على (نشر ثقافة التسامح بين الطلبة مع بعضهم ومع الأخرين) بمتوسط حسابي

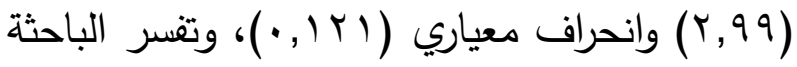
ذلك لما يلاحظه أعضاء هيئة التدريس من إشكاليات

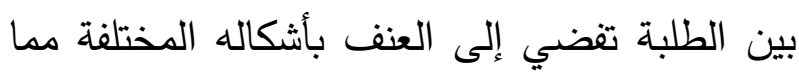
يقتضي التركيز على قيمة التسامح فكانت ضمن بلى لئ العبارات الأعلى ترتيباً في البعد.

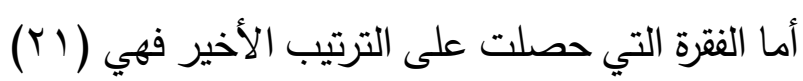
والتي تتص على (تتبل الرأي الأخر وفق الضوابط الشرعية والأخلاقية) بمتوسط حسابي (Y,QV) وانحراف معياري (9 • ץ · · ) بالرغم من أن العبارة نالت

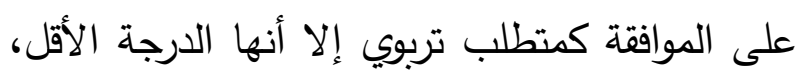


أماني محمد بن محمد قليوبي

جدول ( • 1) يوضح المتوسطات الحسابية والانحرافات المعيارية لكل فقرة من فقرات بعد (تعزيز الخصائص الثخصية والنفسية) مع رتبتها ودرجة تمثيلها

\begin{tabular}{|c|c|c|c|c|}
\hline الفقبة & المعياري الانحراف & الحستبي & 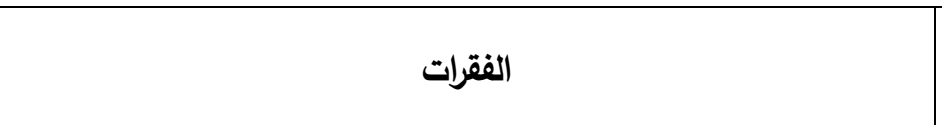 & الفقرة \\
\hline 1 & .121 & 2.99 & تتخاذ القراري، تقبل النقية) لدى الطلبة مثل (الإيجابية، المرونة، تقدير الذات، إدارة الوقت، & $r \wedge$ \\
\hline 13 & .196 & 2.96 & تعزيز الشعور بالمسؤولية الاخلاقية تجاه المجتمع & rq \\
\hline 9 & .156 & 2.98 & تعزيز الثعور بالمسؤولية الاجتماعية تجاه المجتمع & $r$ r. \\
\hline 12 & .207 & 2.96 & الالتزام بالمعايير الاجتماعية (الأعراف والتقاليد) & T \\
\hline 8 & .156 & 2.98 & تعزيز نظرة الطلبة الإيجابية نحو قيم العمل والانتاج & rt \\
\hline 13 & .121 & 2.99 & تعزيز ثقة الطلبة في قدرتهم على التغيير الإيجابي والعطاء المثمر & $r r$ \\
\hline 4 & .121 & 2.99 & 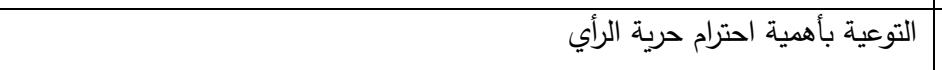 & $r \varepsilon$ \\
\hline 16 & .227 & 2.95 & تعزيز ممارسة الحريات الفردية بكل مسؤولية & ro \\
\hline 18 & .301 & 2.94 & إتقان استخدام التكنولوجيا الحديثة & ry \\
\hline 10 & .156 & 2.98 & تتمية القدرة على التعلم الذاتي & $r v$ \\
\hline 14 & .196 & 2.96 & تنمية القدرة على حل المشكلات بأسلوب علمي سليم & rᄉ \\
\hline 19 & .293 & 2.91 & تعلم اللغات الأخرى عند الضرورة & $r q$ \\
\hline 2 & .121 & 2.99 & تنمية شعور المسؤولية تجاه النفس والأسرة والمجتمع & $\varepsilon$. \\
\hline 5 & .099 & 2.99 & غرس روح المبادرة للأعمال التطوعية والخيرية & $\S$ \\
\hline 11 & .156 & 2.98 & تعزيز روح المنافسة الشريفة بين الأقران & $\varepsilon r$ \\
\hline 17 & .227 & 2.95 & تنمية مهارات ريادة الأعمال والأفكار الريادية & $\varepsilon r$ \\
\hline 15 & .207 & 2.96 & التحصين من المخدرات التقليدية والالكترونية & $\varepsilon \varepsilon$ \\
\hline 6 & .121 & 2.99 & إزكاء روح الأصالة العربية من ( كرم- شجاعة-شهامة- مرؤة- إغاثة الملهوف) & $\leqslant 0$ \\
\hline 7 & .121 & 2.99 & نبذ العنف والتطرف والتمييز بكل أشكاله & $\leqslant 7$ \\
\hline & .10993 & 2.9666 & \multicolumn{2}{|c|}{ تعزيز الخصائص الثخصية والنفسية } \\
\hline & .07395 & 2.9756 & \multicolumn{2}{|c|}{ تعزيز الثخصية السعودية } \\
\hline
\end{tabular}

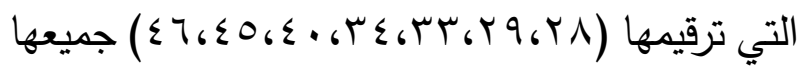
بمتوسط حسابي (r,99) وتتص هذه الفقرات على ترسيخ القيم الشخصية لدى الطلبة مثل (الإيجابية، المرونة، تقدير الذات، إدارة الوقت، اتخاذ القرار، تقبل النقد) بانحراف معياري ( ا I , • ) ومما لا شك فيه أن
تبين دن الجدول السابق أن المتوسط العام للبعد كان

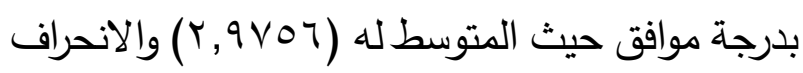
المعياري (0 (ه V •, •)، والموافقة على جميع فقرات البعد تئكد أهمية المتطلبات التربويـة التي يشملها، كما تبين أن أعلى متوسط من بين فقرات البعد هي الفقرات 
عليها مرتفعة أيضاً كونها من الخصائص التي تميز

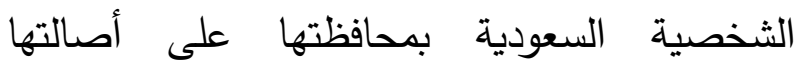
وعروبتها والتأكيد عليها من قبل عينة البحث، والفقرة رقم (T؟) و التي تتص على (نبذ العنف والتطرف والتمييز بكل أشكاله) نظراً لخطورة العنف والتطرف والتمييز باعتبارهم من أخطر المهددات الأمنية على لفئ الشخصية السعودية فكراً وسلوكاً، مما يستدعي التأكيد على نبذه والتحذير منه.

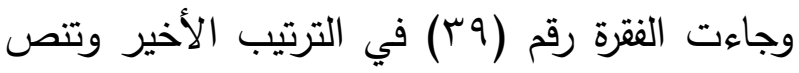
على (تعلم اللغات الأخرى عند الضرورة) بمتوسط

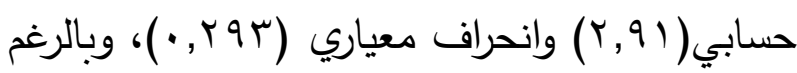
من أن العبارة نالت على الموافقة كمنطلب تربوي إلا

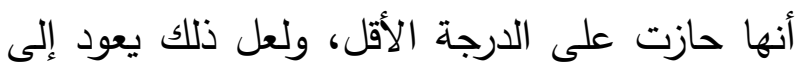

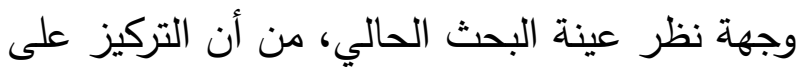
المتطلبات الأخرى أهم في تعزيز الثخصية من تعلم لغات أخرى بحسب الحاجة وعند الضرورة، باعتبار أن عدم تعلمها لا يؤثر من وجهة نظرهم على شخصية الطالب بالقدر الذي يؤثر به غياب باقي المتطلبات. وجاء المتوسط العام لمتطلبات تعزيز الشخصية السعودية لدى طلاب الجامعة من وجهة نظر أعضاء هيئة التدريس -عينة البحث- مرتفعاً، حيث المتوسط

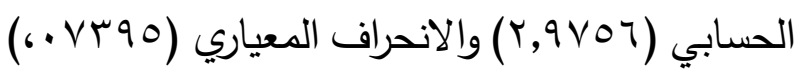
مما يؤكد أهمية المتطلبات التربوية لتعزيز الشخصية السعودية في جميع الأبعاد. وجاء البعد الخاص بتعزيز (القيم الإسلامية والوطنية) في المرتبة الأولى، بمتوسط حسابي (YAY,9)
ترسيخ القيم الشخصية لدى الطلبة يمثل نقطة جوهرية في تعزيز الخصائص الثخصية والنفسية للطلبة، بل تعد نقطة الانطلاق في ذلك التعزيز،

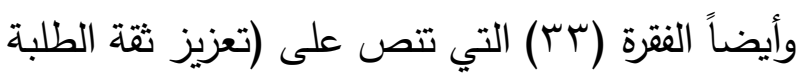
في قدرتهم على التغيير الإيجابي والعطاء المثر)

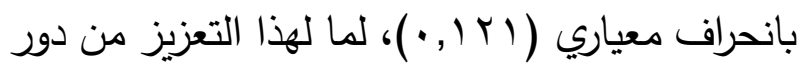
في تحفيزهم على التغيير نحو الأفضل بالثقة في أنفسهم وبرسم ملامح مشرقة لشخصياتهم وقدراتهم نحو العطاء بمجالاته المختلفة؛ كون التنمية مرتبطة بهر

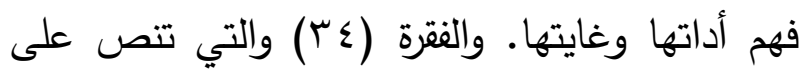
(التوعية بأهمية احترام حرية الرأي) بانحراف معياري

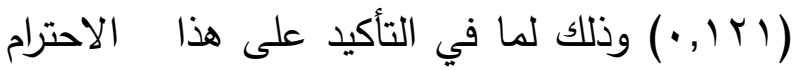
من تأكيد على احترام الحرية الثخصية واحترام الآراء المختلفة وعدم تسفيهها لما يترتب على ذلك من لن الكرام

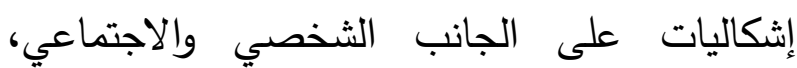
والفقرة(•؛) والتي تتص على (تتمية شعور المسؤولية تجاه النفس والأسرة والمجتمع) بانحراف معياري

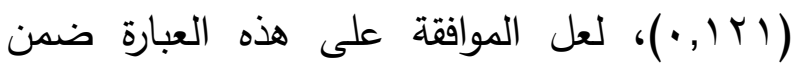
العبارات الأعلى في البعد لما يمثله الشعور بالمسؤولية من قوة داخلية تحرك الفرد نحو بذل ما في وسعه لنها لتطوير ذاته وإمكاناته ليكون أهلا لتحمل المهام

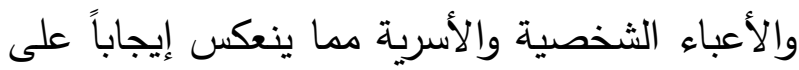
شخصيته ، فيسعى لخدمة مجتمعه وحماية وطنه، والفقرة (0ء) والتي تنص على (إزكاء روح الأصالة العربية من (كرم- شجاعة-شهامة- مرؤة- إغاثة

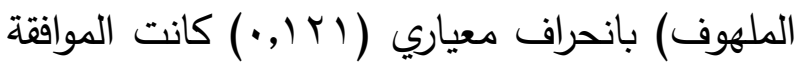


الإسلامية والمثل العليا، لذا كانت استجابات عينة البحث أعلى في بعد تعزيز القيم الإسلامية والوطنية.

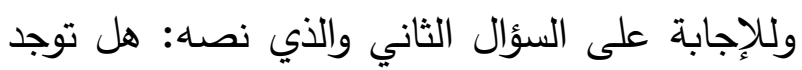
فروق ذات دلالة إحصائية بين متوسط استجابات أعضاء هيئة التدريس -عينة البحث -حول المتطلبات التربوية لتعزيز الشخصية السعودية للى طلبة الجامعة

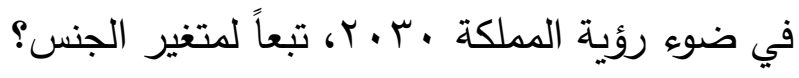
تم صياغة الفرضية الآتية لا توجد فروق ذات دلالة إحصائية بين متوسط استجابات أعضاء هيئة التدريس -عينة البحث - حول المتطلبات التربوية لتعزيز

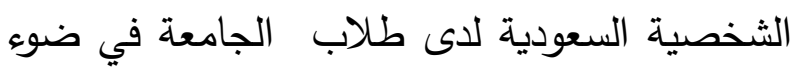

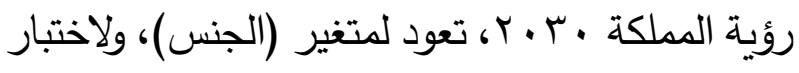

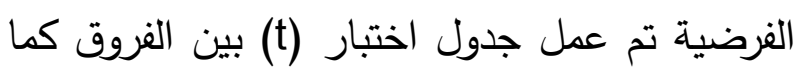

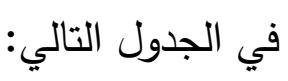

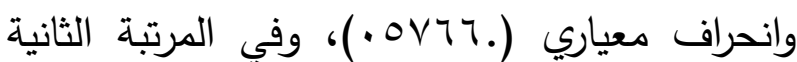
البعد الخاص بتعزيز (الهوية الوطنية) بمتوسط حسابي

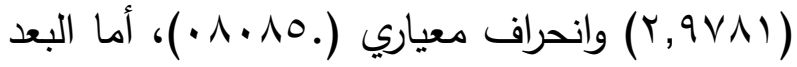
الذي حصل على الترتيب الثالث هو البعد الخاص

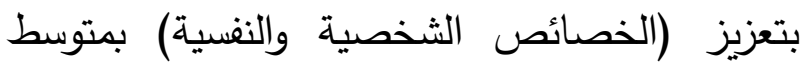

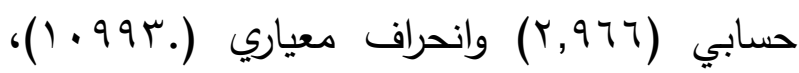
ويعتبر هذا الترتيب منطقياً فتعزيز القيم الإسلامية جاءت في المرتبة الأولى حيث تعتبر مكوناً أساسياً في الثخصية الوطنية وكذلك القيم الوطنية مرتبطة

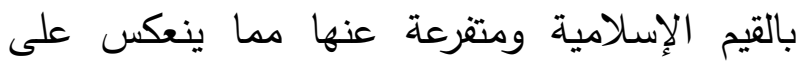
تعزيز الهوية الوطنية والتي جاءت في المرتبة الثانية، وتعزيز الجانب الشخصي والنفسي للفرد، والاهتمام به فرع عن الاهتمام بالأصل المنبثق من الإسلام بقيمه والبهي

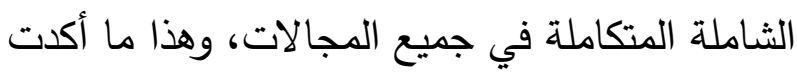
عليه وثيقة التعليم في المملكة بتزويد الطلبة بالقيم

جدول (1 1) اختبار (t) للمتطلبات التربوية لتعزيز الثخصية السعودية تبعاً لمتفير (الجنس)

\begin{tabular}{|c|c|c|c|c|c|c|c|}
\hline الدلالة & $\begin{array}{c}\text { اختبار } \\
\text { t }\end{array}$ & الحرية & الانحراف & الوسابي & العدد & الجنس & البعد \\
\hline \multirow[t]{2}{*}{0,075} & \multirow[t]{2}{*}{1,789} & \multirow[t]{2}{*}{200} & .03945 & 2.9872 & 78 & ذكر & \multirow{2}{*}{ الأول (تغزيز الهوية الوطنية) } \\
\hline & & & .06613 & 2.9724 & 124 & انثى & \\
\hline \multirow[t]{2}{*}{0,071} & \multirow[t]{2}{*}{1,818} & \multirow[t]{2}{*}{200} & .01896 & 2.9951 & 78 & ذكر & \multirow{2}{*}{ الثاني (تعزيز القيم الإسلامية والوطنية) } \\
\hline & & & .10141 & 2.9739 & 124 & انثي & \\
\hline \multirow[t]{2}{*}{0,790} & \multirow[t]{2}{*}{0,431} & \multirow[t]{2}{*}{200} & .10345 & 2.9744 & 78 & ذكر & \multirow{2}{*}{ والنفشية) (لتعزيز الخصائص الثخصية } \\
\hline & & & .11396 & 2.9618 & 124 & انثى & \\
\hline \multirow[t]{2}{*}{0,131} & \multirow[t]{2}{*}{1,518} & \multirow[t]{2}{*}{200} & .04914 & 2.9855 & 78 & ذكر & \multirow{2}{*}{ تعزيز الثخصية السعودية } \\
\hline & & & .08558 & 2.9694 & 124 & انثى & \\
\hline
\end{tabular}

استجابات أعضاء هيئة التدري -عينة البحث -حول

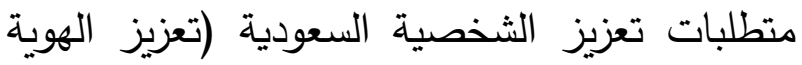
وبحسب الجدول السابق تم قبول الفرضية الصفرية

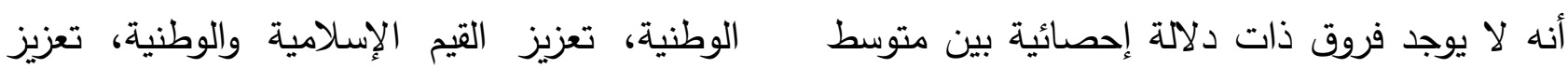


التربوية لتعزيز الشخصية السعودية لدى طلبة الجامعة

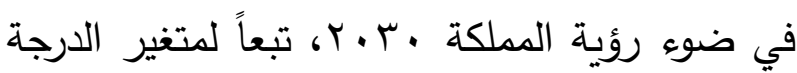

العلمية؟

تم صياغة الفرضية الآتية: لا توجد فروق ذات دلالة إحصائية بين متوسط استجابات أعضاء هيئة التدريس

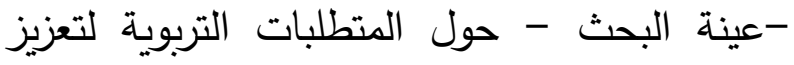
الشخصية السعودية من خلال تعزيز (الهوية الوطنية

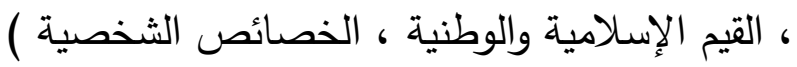

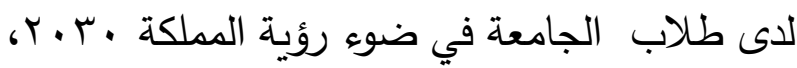

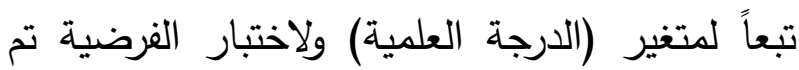

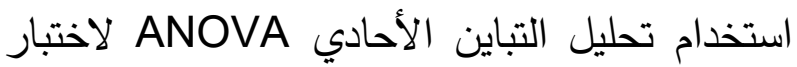
الفروق بين المتوسطات كما في الجدول التالي:

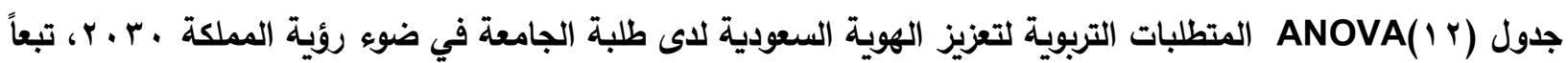
لمتغير الارجة العلمية

\begin{tabular}{|c|c|c|c|c|c|c|}
\hline الدالالة & $\mathbf{F}$ & المتوسط & 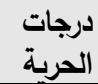 & المجمبعات & التداخل & البعد \\
\hline .382 & .966 & .003 & 2 & .006 & المجموعات & \multirow{3}{*}{ الأول (تعزيز الهوية الوطنية) } \\
\hline & & .003 & 199 & .662 & المجموعات & \\
\hline & & & 201 & .668 & المجموع & \\
\hline \multirow[t]{3}{*}{.302} & 1.206 & .008 & 2 & .016 & المجموعات & \multirow{3}{*}{ الثاني (تعزيز القيم الإسلامية والوطنية) } \\
\hline & & .007 & 199 & 1.298 & المجموعات & \\
\hline & & & 201 & 1.314 & المجموع & \\
\hline \multirow[t]{3}{*}{.163} & 1.833 & .022 & 2 & .044 & المجموعات & \multirow{3}{*}{ الثالث (تعزيز الخصائص الثخصية والنفسية) } \\
\hline & & .012 & 199 & 2.385 & المجموعات & \\
\hline & & & 201 & 2.429 & المجموع & \\
\hline \multirow[t]{3}{*}{.240} & 1.439 & .008 & 2 & .016 & بين المجموعات & \multirow{3}{*}{ تعزيز الثخصية السعودية } \\
\hline & & .005 & 199 & 1.084 & داخل & \\
\hline & & & 201 & 1.099 & المجموع & \\
\hline
\end{tabular}

وهذا يعني أنه لا يوجد فروق ذات دلالة إحصائية بين متوسط استجابات أعضاء هيئة التدريس -عينة البحث

الخصائص الشخصية والنفسية) لدى طلبة الجامعة

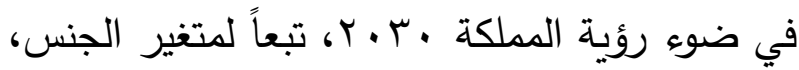
وذلك يؤكد أن وجهة نظر عينة البحث(الذكور والإناث) متفقة وتتبثق من نظرتهم التربوية المستندة

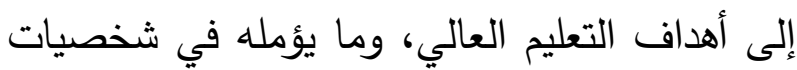

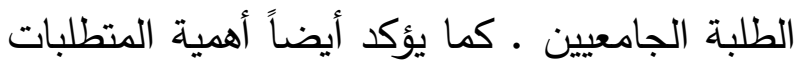
لطلبة الجامعات لكلا الجنسين (الذكور والإناث)،

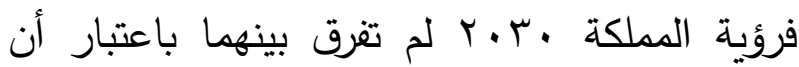
العنصر البشري بشقيه هو أداة التتمية وهدفها.

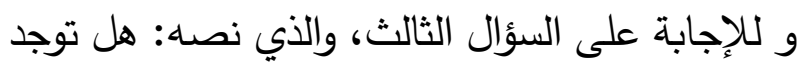
فروق ذات دلالة إحصائية بين متوسط استجابات

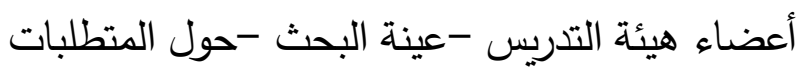


تم صياغة الفرضية الآتية: لا توجد فروق ذات دلالة إحصائية بين متوسط استجابات أعضاء هيئة التدريس -عينة البحث -حول المتطلبات التربوية لتعزيز الثخصية السعودية من خلا (تعزيز الهوية الوطنية، تعزيز القيم الإسلامية والوطنية، تعزيز الخصائص

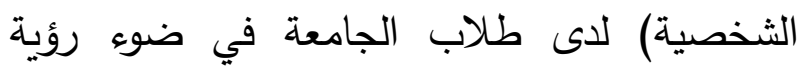
المملكة .ب.r.r، تعود لمتغير (القسم) ولاختبار

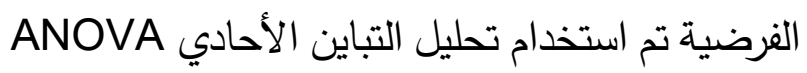
لاختبار الفروق بين المتوسطات كما في الجدول

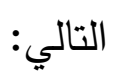

-حول متطلبات (تعزيز الهوية الوطنية، تعزيز القيم الإسلامية والوطنية، تعزيز الخصائص الثخصية والنفسية) للى طلبة الجامعة في ضوء رؤية المملكة

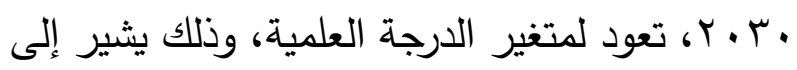
أن أعضاء هيئة التدريس باختلاف درجاتهم العلمية يؤكدون أهمية المتطلبات التربوية لتعزيز الثخصية

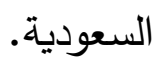
وللإجابة على السؤال الرابع، والذي نصده: هل توجد فروق ذات دلالة إحصائية بين متوسط استجابات

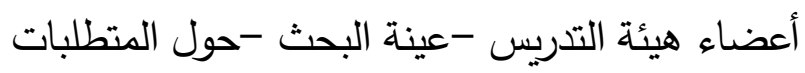
التربوية لتعزيز الشخصية السعودية لدى طلبة الجامعة هينه

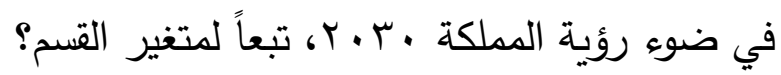

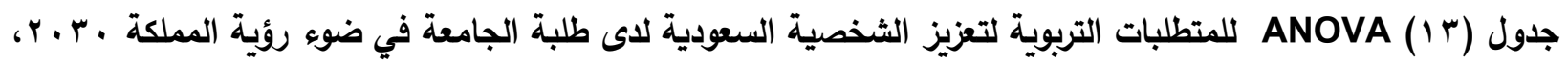

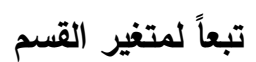

\begin{tabular}{|c|c|c|c|c|c|c|}
\hline مستلوي & $\mathbf{F}$ & المربعات & الحرجية & المربموتات & التداخل & البعد \\
\hline .213 & 1.386 & .005 & 7 & .032 & بين المجموعات & \multirow{3}{*}{ الأول (تعزيز الهوية الوطنية) } \\
\hline & & .003 & 194 & .636 & داخل المجموعات & \\
\hline & & & 201 & .668 & الدجموع & \\
\hline .113 & 1.692 & .011 & 7 & .076 & بين المجموعات & \multirow{3}{*}{ الثاني (تغزيز القيم الإسلامية والوطنية) } \\
\hline & & .006 & 194 & 1.238 & داخل المجموعات & \\
\hline & & & 201 & 1.314 & المجموع & \\
\hline .008 & 2.807 & .032 & 7 & .223 & بين المجموعات & \multirow{3}{*}{ الثالث (تعزيز الخصائص الثخصية والنفسية) } \\
\hline & & .011 & 194 & 2.206 & داخل المجموعات & \\
\hline & & & 201 & 2.429 & المجموع & \\
\hline .033 & 2.232 & .012 & 7 & .082 & بين المجموعات & \multirow{3}{*}{ تعزيز الشخصية السعودية } \\
\hline & & .005 & 194 & 1.017 & داخل المجموعات & \\
\hline & & & 201 & 1.099 & الدجموع & \\
\hline
\end{tabular}

ذات دلالة إحصائية بين متوسط استجابات أعضاء هيئة التدريس -عينة البحث -حول المتطلبات التربوية لتعزيز الشخصية السعودية في البعدين الأول والثاني (تعزيز الهوية الوطنية، تعزيز القيم الإسلامية
وبحسب الجدول السابق تم قبول الفرضية الصفرية تبعا لمتغير القسم حيث أن (sig>0.05) في لبحن المتطلبين (تعزيز الهوية الوطنية، تعزيز القيم

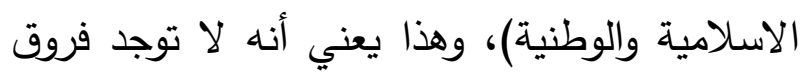


متوسط استجابات أعضاء هيئة التدريس -عينة البحث -حول المتطلبات التربوية لتعزيز الشخصية السعودية بشكل عام ومتطلبات بُعد (تعزيز الخصائص الشخصية والنفسية) لاى طلاب الجامعة في ضوء رؤية المملكة . ب. r. تبعاً لمتغير (القسم). ولمعرفة تلك الفروق تم عمل اختبار توكي (Tukey) وكانت الفروق كما في الجدولين الآتيين:
والوطنية) لدى طلاب الجامعة في ضوء رؤيسة المملكة • . . ץ، تعود لمتغير (القسم). بينما تم رفض الفرضية الصفرية تبعا لمتغير القسم في متطلبات بُعد (تعزيز الخصائص الشخصية والنغسية) وكذلك في متطلبات تعزيز الشخصية السعودية بشكل عام لدى طلاب الجامعة في ضوء رؤية المملكة • . . . . تبعاً لمتغير (القسم) مما يعني قبول الفرضية البديلة وهذا يعني وجود فروق ذات دلالة إحصائية بين جدول ( 1 ) يوضح الفروق بين الأقسام من خلال اختبار توكي Tukey حول (تعزيز الخصائص الثخصية والنفسية) لاى

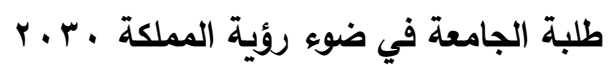

\begin{tabular}{|c|c|c|c|}
\hline مستوى الدلالة & الفرق بين المتوسطات & القسم (Y) & القسم (1) \\
\hline 0,045 & $0.09371^{*}$ & إدارة تربوية وتخطيط & \multirow{4}{*}{ تربية إسلامية ومقارنة } \\
\hline 0,010 & $0.06708^{*}$ & تربية بدينة & \\
\hline 0,017 & $0.08938^{*}$ & طفولة مبكرة & \\
\hline 0,047 & $0.07192^{\circ}$ & علم نفس & \\
\hline
\end{tabular}

من الجدول السابق يتبين أن هناك فروقاً بين استجابات المسلم بخصائصهما المتعددة؛ لما لها من قدرة على أعضاء هيئة التدريس في قسم (التربية الإسلامية تهيئته للقيام بمهام الاستخلاف في الأرض، وأن يكون والمقارنة) وبين كل من أعضاء هيئة التدري في كل قدوة لغيره، مما جعل الفروق لصالح أعضاء قسم من الأقسام (إدارة تربوية وتخطيط، التربية البدنية، التربية الإسلامية. كما أن الجدول الآتي يوضح الفروق بين الأقسام حول الطفولة المبكرة، علم النفس) في البعد الثالث: (تعزيز الخصائص الثخصية والنفسية) لصالح قسم التربية الإسلامية والمقارنة، حيث أن التربية الإسلامية تسعى إلى تكامل الجانبين الشخصي والنفسي في شخصية لمتغير القسم: 


$$
\text { أماني محمد بن محمد قليوبي }
$$

جدول (0 1) يوضح الفروق بين الأقسام من خلال اختبار توكي Tukey حول (متطلبات تعزيز الثخصية السعودية) لاى

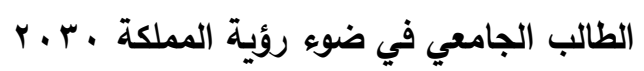

\begin{tabular}{|c|c|c|c|}
\hline مستوى الدلالة & المتوسطات بين & القسم & (1) \\
\hline 0,038 & 0,05961 & تربية بدنية & تربية إسلامية ومقارنة \\
\hline
\end{tabular}

يتضح من الجدول السابق أن هنالك فروق بين قسم التربوية لتعزيز الشخصية السعودية لدى طلبة الجامعة التربية الإسلامية وقسم التربية البدنية حول تعزيز في ضوء رؤية المملكة .ب. اب، تبعاً لمتغير سنوات متطلبات الشخصية السعودية من وجهة نظر أعضاء الخبرة؟ تم صياغة الفرضية الآتية: لا توجد فروق ذات دلالة هيئة التدريس ولصالح التربية الإسلامية والمقارنة، إحصائية بين متوسط استجابات أعضاء هيئة التدريس وتفسر الباحثة تلك الفروق إلى شمولية نظرة التربية -عينة البحث -حول المتطلبات التربوية لتعزيز الإسلامية لجميع جوانب الثخصية الإنسانية الشخصية السعودية من خلال (تعزيز الهوية الوطنية، واهتمامها بجميع أبعادها مما أثر في نظرة أعضاء هيئة التدريس بالقسم نحو التأكيد على المتطلبات تعزيز القيم الإسلامية والوطنية، تعزيز الخصائص التربوية لتعزيز الشخصية السعودية بجميع أبعادها الشخصية) لدى طلاب الجامعة في ضوء رؤية المملكة .r.r.r. تبعاً لمتغير (سنوات الخبرة)، فجعلت الفروق لصالحهم. ولاختبار الفرضية تم استخدام تحليل التباين الأحادي وللإجابة على السؤال الخامس والذي نصهـ: هل توجد فروق ذات دلالة إحصائية بين متوسط استجابات لاختبار الفروق بين المتوسطات كما في أعضاء هيئة التدريس -عينة البحث -حول المتطلبات الجدول التالي: 


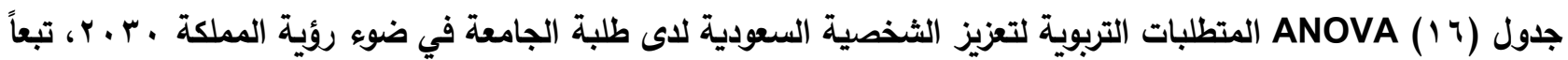

\begin{tabular}{|c|c|c|c|c|c|c|}
\hline مستوى الدلالة & $F$ & متوسط & الحرية & المربعات & التداخل & البعد \\
\hline \multirow[t]{3}{*}{.913} & .091 & .000 & 2 & .001 & المجموعات & \multirow{3}{*}{ الأول (تعزيز } \\
\hline & & .003 & 199 & .668 & المجموعات & \\
\hline & & & 201 & .668 & المجموع & \\
\hline \multirow[t]{3}{*}{.448} & .807 & .005 & 2 & .011 & المجموعات & \multirow{3}{*}{ الإسلانية (تعزيز القيم } \\
\hline & & .007 & 199 & 1.303 & المجموعات & \\
\hline & & & 201 & 1.314 & المجموع & \\
\hline \multirow[t]{3}{*}{.284} & 1.266 & .015 & 2 & .031 & المجموعات & \multirow{3}{*}{ الثالث (تعزيز الثنص الثخصية } \\
\hline & & .012 & 199 & 2.399 & المجموعات & \\
\hline & & & 201 & 2.429 & المجموع & \\
\hline \multirow[t]{3}{*}{.491} & .714 & .004 & 2 & .008 & المجموعات & \multirow{3}{*}{ تعزيز الشخصية السعودية } \\
\hline & & .005 & 199 & 1.091 & المجموعات & \\
\hline & & & 201 & 1.099 & المجموع & \\
\hline
\end{tabular}

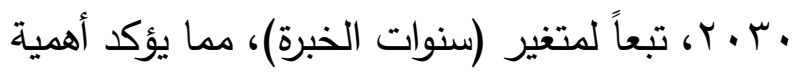
تلك المتطلبات حيث لم يؤثز عدد سنوات الخبرة في العمل الأكاديمي لأعضاء هيئة التدريس-عينة البحث- - على درجة موافقتهم عليها. وبذلك تمت الإجابة عن أسئلة البحث التي تهدف إلى تحديد أهم المتطلبات التربوية لتعزيز الشخصية السعودية في ثلاثة أبعاد هي (تعزيز الهوية الوطنية، تعزيز القيم الإسلامية والوطنية، تعزيز الخصائص
وبحسب الجدول السابق تم قبول الفرضية الصفرية تبعا لمتغير الجنس حيث إن (sig>0.05)، وهذا يعني أنه لا توجد فروق ذات دلالة إحصائية بين متوسط استجابات أعضاء هيئة التدريس -عينة البحث -حول المتطلبات التربوية لتعزيز الشخصية السعودية من خلال (تعزيز الهوية الوطنية، تعزيز القيم الإسلامية والوطنية، تعزيز الخصائص الشخصية والنفسية) لدى طلاب الجامعة في ضوء رؤية المملكة 
المتطلبات التربوية لتعزيز الثخصية السعودية في البعدين الأول والثاني (تعزيز الهوية الوطنية، تعزيز القيم الإسلامية والوطنية) لدى طلاب الجامعة في

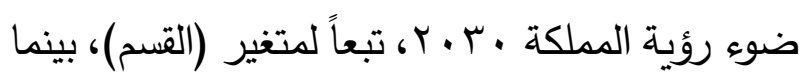
توجد فروق بين أعضاء هيئة التدريس في قسم التربية الاسلامية والمقارنة وبين كل من أعضاء هيئة التدريس فئس فئس التربية في كل من الأقسام (إدارة تربوية وتخطيط، التربية البدنية، الطفولة المبكرة، علم النفس) في البعد الثالث

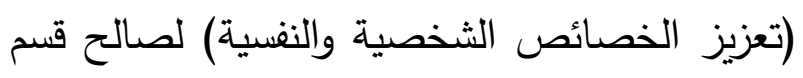
التربية الاسلامية والمقارنة.

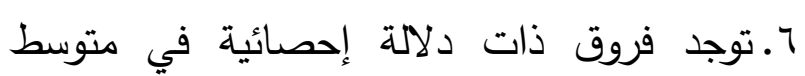
استجابات أعضاء هيئة التدريس -عينة البحث-بين (قسم التربية الاسلامية والمقارنة) و و(قسم التربية البدنية) حول متطلبات تعزيز الشخصية السعودية لصالح قسم التربية الإسلامية والمقارنة.

\section{التوصيات}

في ضوء نتائج البحث الحالي توصي الباحثة بما يلي:

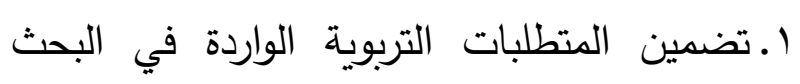
الحالي في الخطط الاستراتيجية للجامعات السعودية، بما يسهم في تحسين مخرجاتها وفقاً لتطلعات رؤية المملكة • r • ب للشخصية السعودية. r. عقد برامج وورش عمل لأعضاء هيئة التدريس

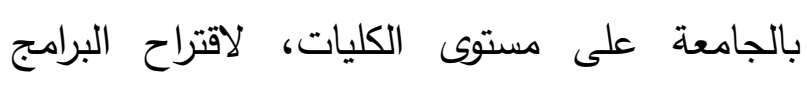
والأساليب التي تمكنهم من تعزيز الشخصية السعودية

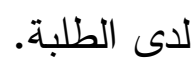

الثخصية والنفسية)، والكثف عن الفروق بين استجابات أعضاء هيئة التدريس -عينة البحث- حول ولئ تحديد المتطلبات التربوية تبعاً للمتغيرات (الجنس، الدرجة العلمية، القسم، سنوات الخبرة). ملخص النتائج

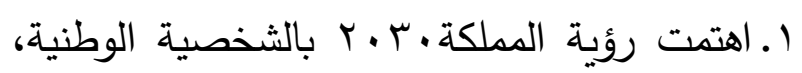
وأفردت لها أحد برامجها الاستراتيجية (برنامج تعزيز الشخصية السعودية)، وقد عُني البحث الحالي بتقديم متطلبات تربوية لتعزيز هذه الشخصية في طلبة الجامعة من وجهة نظر أعضاء هيئة التدريس. r.جاءت موافقة أعضاء هيئة التدريس -عينة

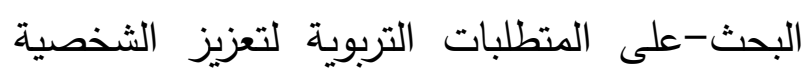
السعودية بدرجة عالية حيث المتوسط الحسابي

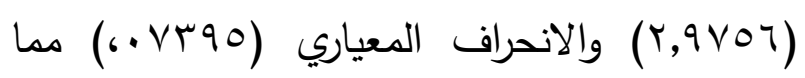
يؤكد أهمية هذه المتطلبات بجميع أبعادها. r. جاء ترتيب الأبعاد وفقا للمتوسط العام كالتالي:

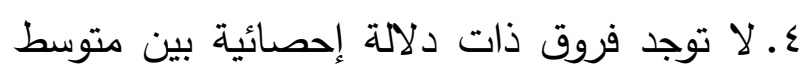

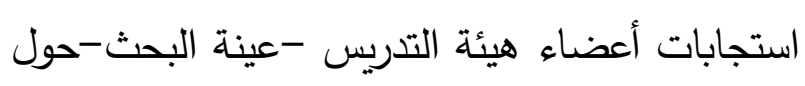

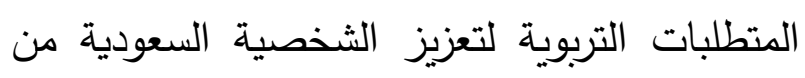
خلا الأبعاد (تعزيز الهوية الوطنية، تعزيز القيم الإسلامية والوطنية، تعزيز الخصائص الثخصية والنفسية) لدى طلاب الجامعة في ضوء رؤية المملكة

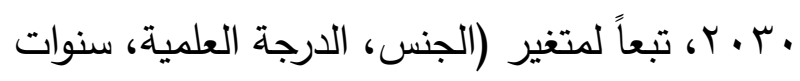
الخبرة). ه. لا توجد فروق ذات دلالة إحصائية بين متوسط

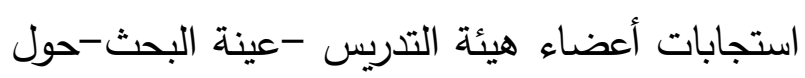


ا. التحديات التي تهدد الشخصية السعودية وسبل مواجتها من وجهة نظر أعضاء هيئة التدريس بالجامعات. r. بستوى وعي الثخصية السعودية بالتحديات التي

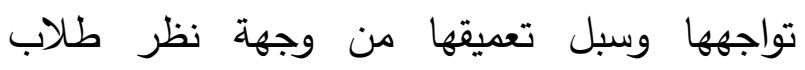

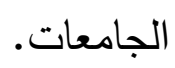
ז.دور الأسرة في تعزيز الشخصية السعودية لدى

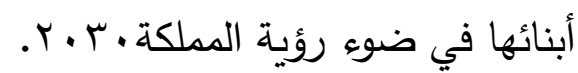

\section{المراجع}

- أباظة، أحمد (Y ( + Y). سيكلوجية الثخصية. دار النهضة العربية. القاهرة.

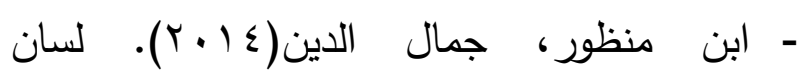
العرب.طس.مجه .دار صادر • لبنان

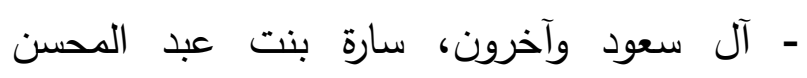

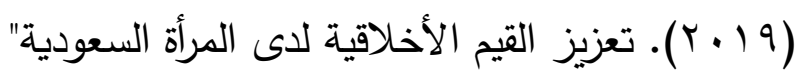

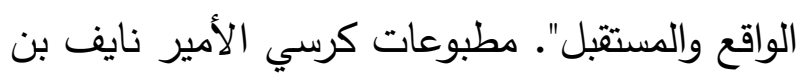
عبد العزيز للقيم الأخلاقية. جدة. الجامعات الحكومية في تعزيز الشخصية السعودية

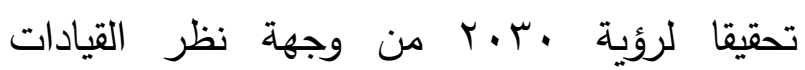

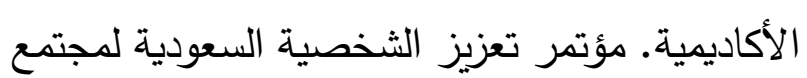
حيوي. جامعة الملك سعود.

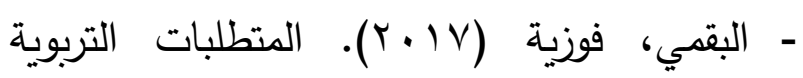
للطالبة الجامعية في ضوء رؤية المملكة العربية

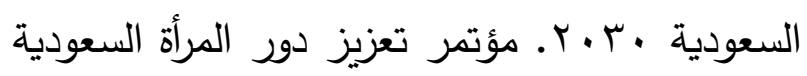

r. تفعيل أوجه التعاون المختلفة بين الجامعة

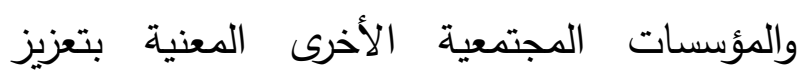

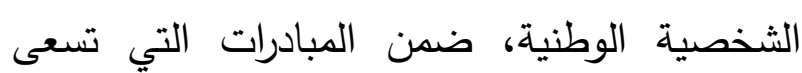
لتحقيق أهداف برنامج تعزيز الشخصية السعودية في التئي

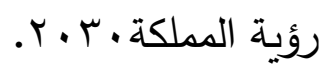
ع.تكثيف وتتويع الأنشطة والفعاليات التي تقدمها عمادات شؤون الطلاب في الجامعات، والتي من النئ ولني شأنها تعزيز الهوية الوطنية للطلبة، وعدم الاكتفاء بالمناسبات الوطنية. هـ ترسيخ القيم الإسلامية والوطنية في شخصية الطلبة من خلال المنظومة التربوية والتعليمية. 7. التركيز خلا العملية التعليمية على بناء مهارات الطلبة الأساسية، والتخصصية، والمهارات الثخصية،

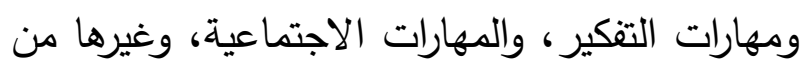

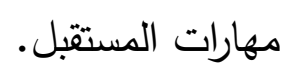
V. تضمين أهداف المقررات وتدريسها، أهداف خاصة بتعزيز الثخصية الوطنية، في جميع المقررات والتخصصات، وأن لا يقتصر ذلك على مقرر التربية الوطنية فقط. ^. تشكيل وحدة تعزيز الشخصية السعودية داخل الجامعة. 9 9. تأسيس نادي طلابي في الجامعات يُعنى بأنشطة ترتبط بالأهداف المباشرة لبرنامج تعزيز الثخصية

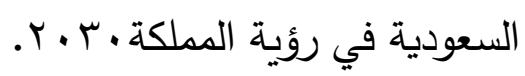
المقترحات تقترح الباحثة إجراء دراسات وبحوث تتناول: 


$$
\text { أماني محمد بن محمد قليوبي }
$$

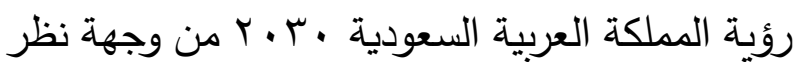
الطلاب. المؤتمر الدولي للهوية الوطنية في ضوء رؤية المملكة العربية السعودية ·. ·. . . جامعة شقراء.

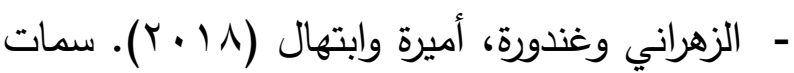
عضو هيئة التدريس في تعزيز الوسطية. المجلة العربية للعلوم التربوية والنفسية.عه. - السالم، ماجدة بنت محمد (·r.r.r). دور كليات التربية في تعزيز الشخصية السعودية لدى الطلاب

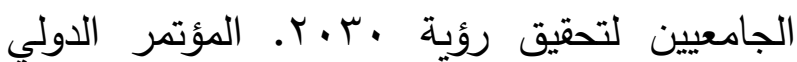
للهوية الوطنية في ضوه رؤية المملكة العربية

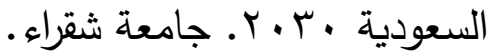
- السبيعي، علي بن مثيب بن دغيم (19 (1). تصور مقترح لتعزيز الثخصية الوطنية السعودية في لي

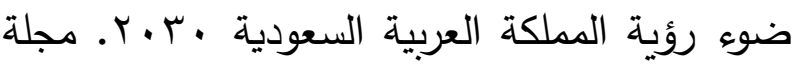
كلية التربية، جامعة كفر الثيخ، كلية التربية، مجو (19

- السبيعي، ماضي بن راشد (19 ( 1) مهددات الهوية الوطنية السعودية وتأثيرها على الوحدة الوطنية. رسالة دكتوراه غير منشورة. جامعة نايف العربية للعلوم

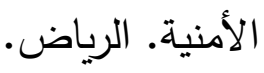

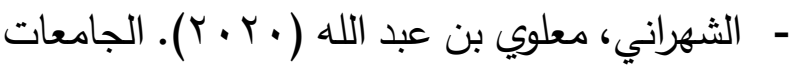
السعودية ودورها في تعزيز الهوية الوطنية في ضوء التحديات المعاصرة. المؤتمر الدولي للهوية الوطنية في ضوء رؤية المملكة العربية السعودية . .r.r. جامعة شقراء.
في تتمية المجتمع في ضوء رؤية المملكة .ب.r.r.

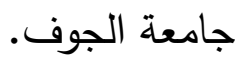
- الثبيتي وحسن، محمد عثمان ومحمد فتحي عبد

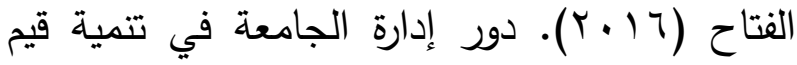
المواطنة لدى طلبة جامعة تبوك. مجلة جامعة طيبة

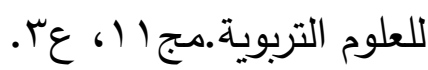

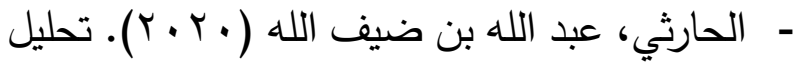
أدوار القيادة الجامعية في تعزيز الهوية الوطنية وفق بـ نموذج ليدكا للتفكير الاستراتيجي. المؤتمر الدولي للهوية الوطنية في ضوء رؤية المملكة العربية

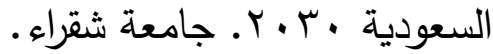

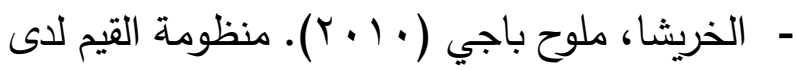
الطلبة المعلمين في كلية العلوم التربوية في جامعة مؤتة والمعلمين في المدارس الحكومية في محافظة

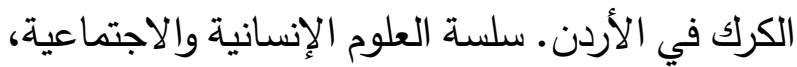

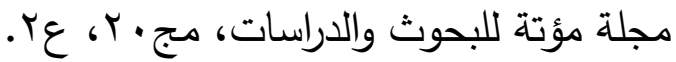
- الخوالدة، تيسير محمد(T (ب). دور عضو هيئة التدريس في الجامعات الأردنية في تنمية قيم المواطنة من وجهة نظر الطلبة. مجلة دراسات العلوم

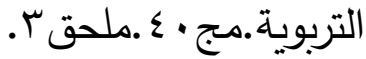
- الدوسري، فاطمة علي ناصر (·r.r). الجامعة في تعزيز الثخصية السعودية نحو الانتماء الاجتماعي والوطني. مؤتمر تعزيز الشخصية السعودية لمجتمع حيوي. جامعة الملك سعود.

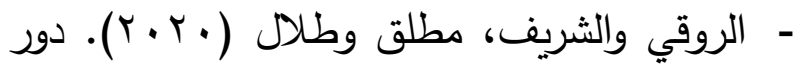
إدارة جامعة شقراء في تعزيز الهوية الوطنية في ضوء 
المجمعة أنموذجاً. المؤتمر الدولي للهوية الوطنية في

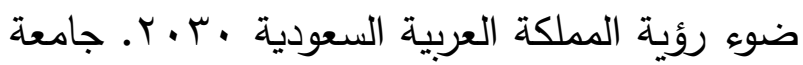
شقراء.

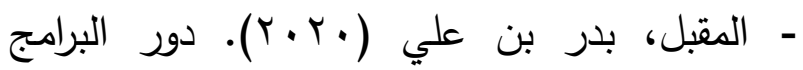

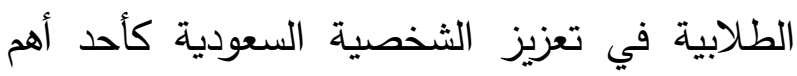
البرامج الاستراتيجية في ضوء رؤية المملكة العربية

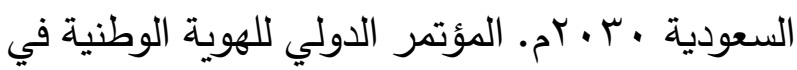
ضوء رؤية المملكة العربية السعودية •r.r.r. جامعة شقراء.

- موقع المؤتمر الدولي، موقع المؤتمر للهوية الوطنية في ضوء رؤية المملكة العربية السعودية https://apps.su.edu.sa/NationalConfere، $r \cdot r$. .nce/pages/e2.html

- هريدي وقليوبي، عادل محمد وخالد بن محمد

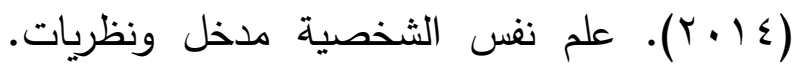

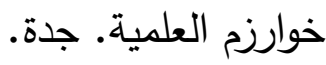

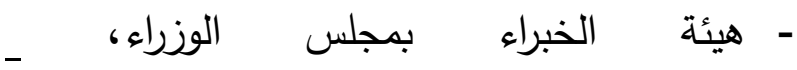
https: //old.boi.gov.sa

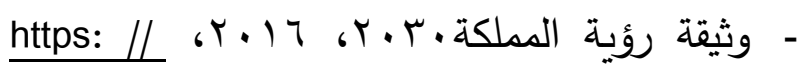
www.vision2030.gov.sa

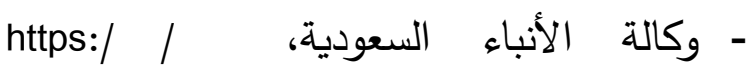
www.spa.gov.sa
- طهه وآخرون، فرج عبد القادر ( د.ت). معجم علم النفس والتحليل النفسي. دار النهضة العربية. بيروت. - العلي وغنية، ريم بنت عبد العزيز وهناء سمير (9 (ب). واقع مناهج الدراسات العليا في تعزيز الثخصية السعودية لاى طلبة كلية التربية- جامعة الأمير سطام بن عبد العزيز من وجهة نظر أعضاء

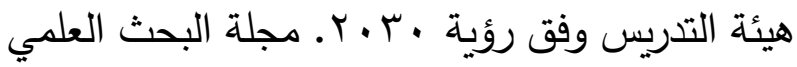
في التربية، جامعة عين شمس- كلية البنات للآداب

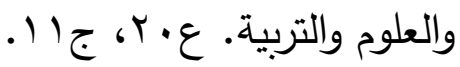

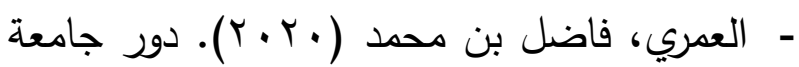
الجوف في تعزيز الثخصية الوطنية لاى طلبتها من وجهة نظر أعضاء هيئة التدري. مؤتمر تعزيز الشخصية السعودية لمجتمع حيوي. جامعة الملك هلك

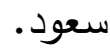
- غانم والقليوبي، محمد حسن وخالد بن محمد

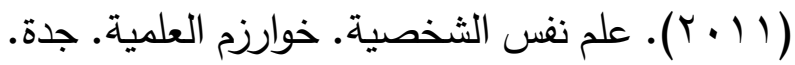
- القطب، سمير عبد الحميد(997 (1). المتطلبات التربوية لبناء الإنسان في المجتمع المصري. رسالة دكتوراه غير منشورة كلية التربية جامعة طنطا. مصر . - كمال الدين والعامري، يحي مصطفى ولولو بنت

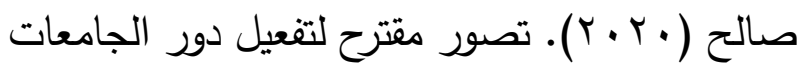

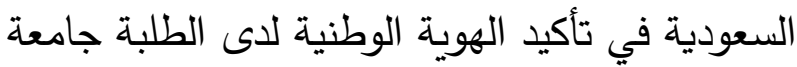




\title{
Educational requirements to enhance the Saudi personality among university students in light of the vision of the Kingdom of Saudi Arabia 2030
}

\author{
from the point of view of faculty members \\ Dr.Amani Mohammed Mohammed Qalyobi \\ Associate Professor at Islamic and Comparative Education Department \\ Faculty of Education -Umm Al Qura University
}

\begin{abstract}
. the aim of the research is to identify the most important educational requirements to enhance the Saudi personality among university students, in light of the vision of the Kingdom of Saudi Arabia 2030 from the point of view of faculty members, and to achieve this goal, the descriptive analytical approach was used, and its tool was applied to (202 members) of the faculty in the College of Education. At Umm Al-Qura University, the research tool - the questionnaire - was divided into three dimensions (strengthening the national identity, promoting Islamic and national values, enhancing personal and psychological characteristics), and the results resulted in the research sample agreeing to the educational requirements to enhance the Saudi personality in all its dimensions with a high degree with an average of $(2,9756)$ and standard

deviation (07395,). There were no differences between the average of the research sample responses about the educational requirements to enhance the Saudi personality in all its dimensions according to the variable (gender, academic degree, years of experience), as well as according to the department variable in the first and second dimensions, while the differences were in the third dimension between the Islamic education department and comparison and each of Sections (Educational Administration and Planning, Physical Education, Early Childhood, Psychology) for the benefit of the Islamic Education Department. There were also differences between the Department of Islamic Education and Comparison and the Department of Physical Education regarding the requirements for strengthening the Saudi personality as a whole in favor of the Department of Islamic Education, and the researcher recommended a set of recommendations, the most important of which are: The need to include the educational requirements contained in this research in the strategic plans of Saudi universities, in order to contribute to improving their outputs. According to the aspirations of the Kingdom's Vision 2030 of the Saudi personality.

Key World: Educational requirements- Enhancing -The Saudi character - University students - The Kingdom's vision 2030
\end{abstract}

